\title{
Integrated management of damping-off diseases. A review
}

\author{
Jay Ram Lamichhane ${ }^{1}$ - Carolyne Dürr ${ }^{2}$ - André A. Schwanck ${ }^{3} \cdot$ Marie-Hélène Robin $^{4}$. \\ Jean-Pierre Sarthou ${ }^{5} \cdot$ Vincent Cellier $^{6} \cdot$ Antoine Messéan $^{1} \cdot$ Jean-Noël Aubertot $^{3}$
}

Accepted: 8 February 2017 / Published online: 16 March 2017

(C) INRA and Springer-Verlag France 2017

\begin{abstract}
Damping-off is a disease that leads to the decay of germinating seeds and young seedlings, which represents for farmers one of the most important yield constraints both in nurseries and fields. As for other biotic stresses, conventional fungicides are widely used to manage this disease, with two major consequences. On the one hand, fungicide overuse threatens the human health and causes ecological concerns. On the other hand, this practice has led to the emergence of pesticide-resistant microorganisms in the environment. Thus, there are increasing concerns to develop sustainable and durable damping-off management strategies that are less reliant on conventional pesticides. Achieving such a goal requires a better knowledge of pathogen biology and disease epidemiology in order to facilitate the decision-making process. It also demands using all available non-chemical tools that can be adapted to regional and specific production situations.
\end{abstract}

Jay Ram Lamichhane

jayram.lamichhane@gmail.com; Jay-Ram.Lamichhane@inra.fr

1 INRA, Eco-Innov Research Unit, Avenue Lucien Brétignières, F-78850 Thiverval-Grignon, France

2 INRA, IRHS 1345, 42 rue George Morel, F-49071 Beaucouzé, France

3 INRA, UMR AGIR 1248, 24 chemin de Borderouge-Auzeville, F-31320 Castanet-Tolosan, France

4 Université de Toulouse, INPT, EI-Purpan, UMR AGIR 1248, 24 chemin de Borderouge-Auzeville, F-31320 Castanet-Tolosan, France

5 Université de Toulouse, INPT, ENSAT, UMR AGIR 1248, 24 chemin de Borderouge-Auzeville, F-31320 Castanet-Tolosan, France

6 INRA, Domaine expérimental d'Epoisses UE 0115, F-21110 Bretenière, France
However, this still is not the case and major knowledge gaps must be filled. Here, we review up to 300 articles of the damping-off literature in order to highlight major knowledge gaps and identify future research priorities. The major findings are (i) damping-off is an emerging disease worldwide, which affects all agricultural and forestry crops, both in nurseries and fields; (ii) over a dozen of soil-borne fungi and fungus-like organisms are a cause of damping-off but only a few of them are frequently associated with the disease; (iii) damping-off may affect from 5 to $80 \%$ of the seedlings, thereby inducing heavy economic consequences for farmers; (iv) a lot of research efforts have been made in recent years to develop biocontrol solutions for damping-off and there are interesting future perspectives; and (v) damping-off management requires an integrated pest management (IPM) approach combining both preventive and curative tactics and strategies. Given the complex nature of damping-off and the numerous factors involved in its occurrence, we recommend further research on critical niches of complexity, such as seeds, seedbed, associated microbes and their interfaces, using novel and robust experimental and modeling approaches based on five research priorities described in this paper.

Keywords Abiotic stresses - Best management practices · Economic losses · Integrated pest management - Interactions · Seed germination $\cdot$ Seedling decay $\cdot$ Soil-borne pathogens

\section{Contents}

1. Introduction

2. Symptoms of damping-off

2.1 Pre-emergence symptoms

2.2 Post-emergence symptoms

2.3 Occurrence of damping-off symptoms 
3. Integrated management of damping-off

3.1 Seed treatment to enhance germination and seedling vigor

3.2 Deployment of host-plant resistance and/or tolerance

3.3 Adoption of best cropping practices

3.4 Timely treatment interventions of seedlings with effective products

3.4.1 Biological control

3.4.2 Chemical control

4. Key challenges and future priorities for damping-off management

4.1 Correct identification of damping-off pathogens including non-secondary colonizers and anastomosis groups

4.2 Determination of potential interactions within and/ or between damping-off pathogens and other living organisms

4.3 A better knowledge of the role of abiotic factors that predispose seeds and seedlings to damping-off diseases

4.4 Development of disease-suppressive seedbed soils with or without conservation agriculture

4.5 Modeling to help design integrated management strategies of damping-off diseases

5. Conclusions and perspectives

Acknowledgements

References

\section{Introduction}

Damping-off is a historical term coined during the early nineteenth century, and represents one of the oldest worldwide nursery problems as discussed in detail in the classic nursery manual (Hartley and Pierce 1917; Tillotson 1917; Hartley 1921). Damping-off was considered "the most serious problem encountered in raising nursery seedlings," and consequently was one of the most focused research subject since the beginning of its description (Hartley and Pierce 1917). The definition of damping-off is not straightforward in the literature. Many authors refer to damping-off as a "disease" (McNew 1960; Horst 2013), while others refer to dampingoff as a "symptomatic condition" (Agrios 2005; Kemerait and Vidhyasekaran 2006). In the former case, damping-off is usually associated to soil-borne pathogens while in the latter case, seed-borne pathogens can promote damping-off. Nevertheless, both interpretations comprehend that dampingoff involves non-germination, prevention of seedling emergence after germination, or the rotting and collapse of seedlings at the soil level.
Overall, damping-off can be caused by a number of biotic or abiotic stresses/factors, which prevent seeds to germinate or seedlings to emerge, including those caused by plantpathogenic bacteria or insect pests notably those living in soil such as Delia spp. Agriotes spp., or Melolontha spp. (Fig. 1). As a consequence, the symptoms associated with damping-off widely vary depending on the type of stress associated with it and time of its occurrence. In general, many fungi and fungilike species (Table 1) have been reported as the most important biotic stress weakening or destroying seeds and seedlings of almost all species including fruit, vegetable, field, ornamental, and forestry crops (Filer and Peterson 1975; Kraft et al. 2000). However, this paper will focus on damping-off caused by Fusarium spp., Rhizoctonia spp., Pythium spp. and Phytophthora spp. since these pathogens are the most frequently associated with damping-off and are considered the most important causal agents of this problem in the literature (Table 1). Furthermore, the role of abiotic stresses will be also discussed as they indirectly affect damping-off occurrence. Favorable abiotic conditions for damping-off problems generally involve excessive soil moisture and excessive overhead misting, lower soil temperatures before emergence, higher soil temperatures after emergence, and overcrowded flats or seedbeds (Wright 1957; Papavizas and Davey 1961; Duniway 1983a; James 2012a; Starkey and Enebak 2012).

In recent years, numerous soil-borne fungi belonging to over a dozen of genera and oomycetes (Pythium and Phytophthora), and some seed-borne fungi, have been reported to cause damping-off on a large number of crops (Table 1). Most of these pathogens are common in agricultural soils and can be spread via non-anthropic and anthropic activities, including water run-off through irrigation or rain (Zappia et al. 2014), soil contamination by improperly sanitized tools, introduction of infected plants (mainly in case of seed-borne pathogens), improperly sanitized greenhouse, and the use of contaminated irrigation water (Papavizas and Davey 1961; Duniway 1983b; Schmitthenner and Canaday 1983; Huang and Kuhlman 1990; James 2012a; Starkey and Enebak 2012). Once established, damping-off pathogens are able to survive for many years in the soil, even in the absence of host plants, either as saprophytes or as living resting structures that are capable of enduring adverse conditions (Menzies 1963). Their wide host range also aids in the longevity of these fungi and fungus-like organisms.

Despite a long history behind and a number of research works conducted on damping-off, it still represents one of the most difficult problems to be managed both in the nurseries and fields. There is no country or geographic area without damping-off problems, on a number of economically important crops. Indeed, since only the beginning of the twenty-first century, almost 50 new reports of damping-off diseases have been noticed on over 30 crops and from over 20 countries (Table 1). This clearly suggests that damping-off problem is 
Fig. 1 Damping-off is either a disease of germinating seeds (preemergence- $A$ ) or young seedlings (post-emergence- $B$ ). The latter also comprises cotyledon blight. While dampingoff is usually refereed to diseases caused by soil-borne fungi or oomycetes, a number of abiotic stresses may contribute to damping-off symptoms $(C)$ (adapted from Landis (2013)

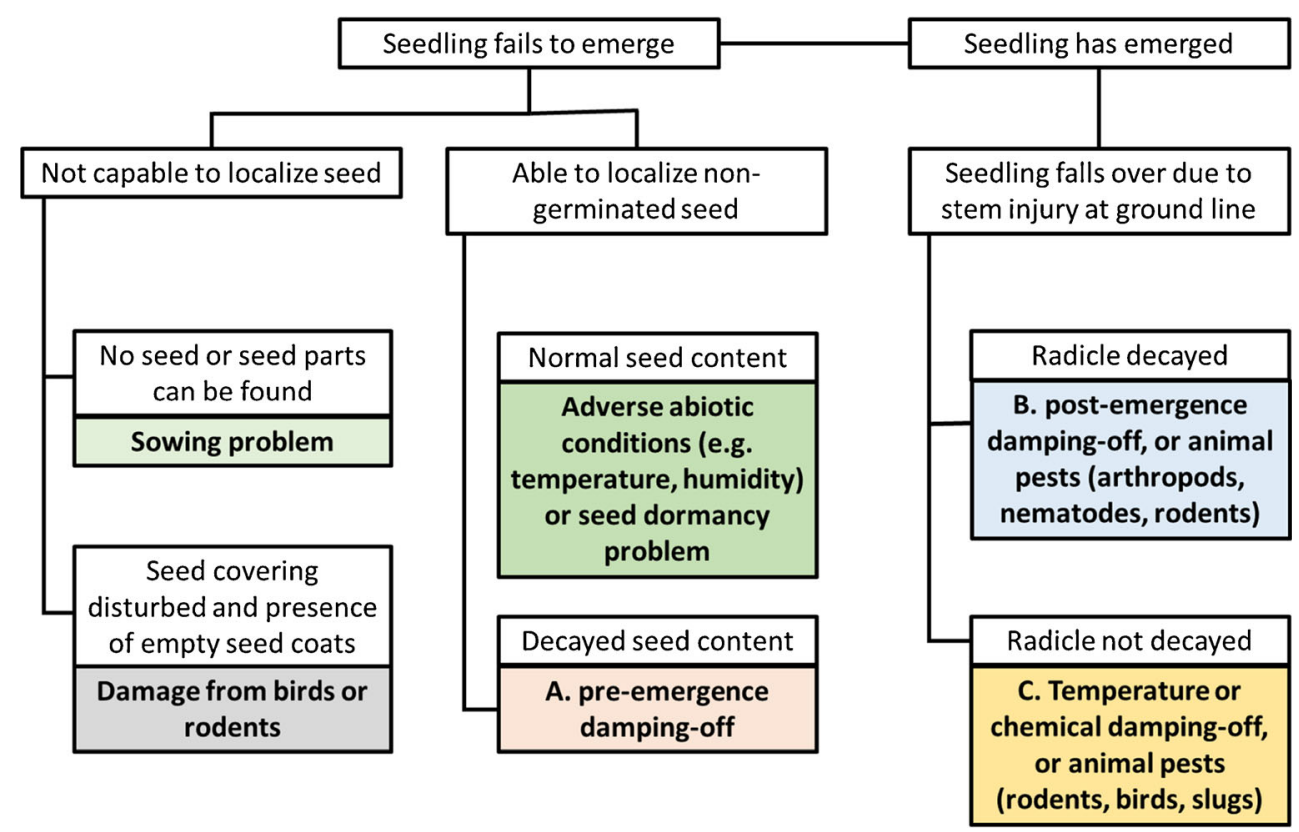

multifaceted, and requires more research efforts to generate further knowledge needed for a durable and sustainable management of damping-off.

Overall, the economic losses due to damping-off are represented by a direct cost, due to damages of seed or seedlings (Fig. 2), and an indirect cost, which consists of an additional cost of replanting and the consequent lower yields due to the later planting dates (Babadoost and Islam 2003; Bacharis et al. 2010; Horst 2013). Although there is no detailed and precise estimation about the real economic impact of damping-off at the global level in monetary terms, a previous study reported that 40 million extra seedlings are planted each year only in Georgia (the USA) to counterbalance losses due to non-viable seeds and damping-off of seedlings (Huang and Kuhlman 1990). Likewise, in 2016, in Brittany (France), the grass or cereal fly Geomyza tripunctata damaged thousands of hectares of maize crops with significant economic losses in the region (BSV 2016). An extensive literature research showed that the incidence of damping-off may vary from 5 to $80 \%$ (Table 1).

In addition to a significant economic importance, there is a considerable environmental impact due to the widespread use of fungicides to manage this frequently occurring problem. For example, the methyl bromide seed treatment and fumigation, a practice forbidden in the European Union (Mouttet et al. 2014), still represents one of the major practices adopted elsewhere, including in the USA, to manage damping-off diseases (Weiland et al. 2013). However, following the Montreal Protocol (UNEP 2006), this practice tends to decline and restrictions for soil fumigation have been increased (Weiland et al. 2013). Nevertheless, other conventional fungicides play an increasingly important role in mitigating seed and seedling damage caused by damping-off pathogens. The frequent use of these fungicides has led to the development of fungicideresistant isolates with additional challenges for farmers to manage damping-off (Taylor et al. 2002; Moorman et al. 2002; Lamichhane et al. 2016).

In light of the high economic impact of damping-off and negative environmental effects generated by conventional fungicide-based control strategies, there is a need to develop alternative and sustainable solutions to manage damping-off. Integrated pest management (IPM) exemplifies a sustainable approach to this aim as it combines preventive measures (e.g., enhancement of seed health, which represents the core of resilient agroecosystems) as well as best agronomic and cultural practices first and pesticide-based tactics as the last option. Therefore, the objectives of this work were to (i) highlight the major features of damping-off diseases, especially those caused by Fusarium spp., Rhizoctonia spp., Pythium spp., and Phytophthora spp.; (ii) report and discuss currently used disease management strategies and knowledge gaps; and (iii) suggest key challenges and future priorities for a sustainable management of damping-off diseases.

\section{Symptoms of damping-off}

Damping-off symptoms can be observed from seeding until the fourth to sixth week post-sowing (Horst 2013). The disease symptoms can be divided in two phases based on the time of its appearance. 


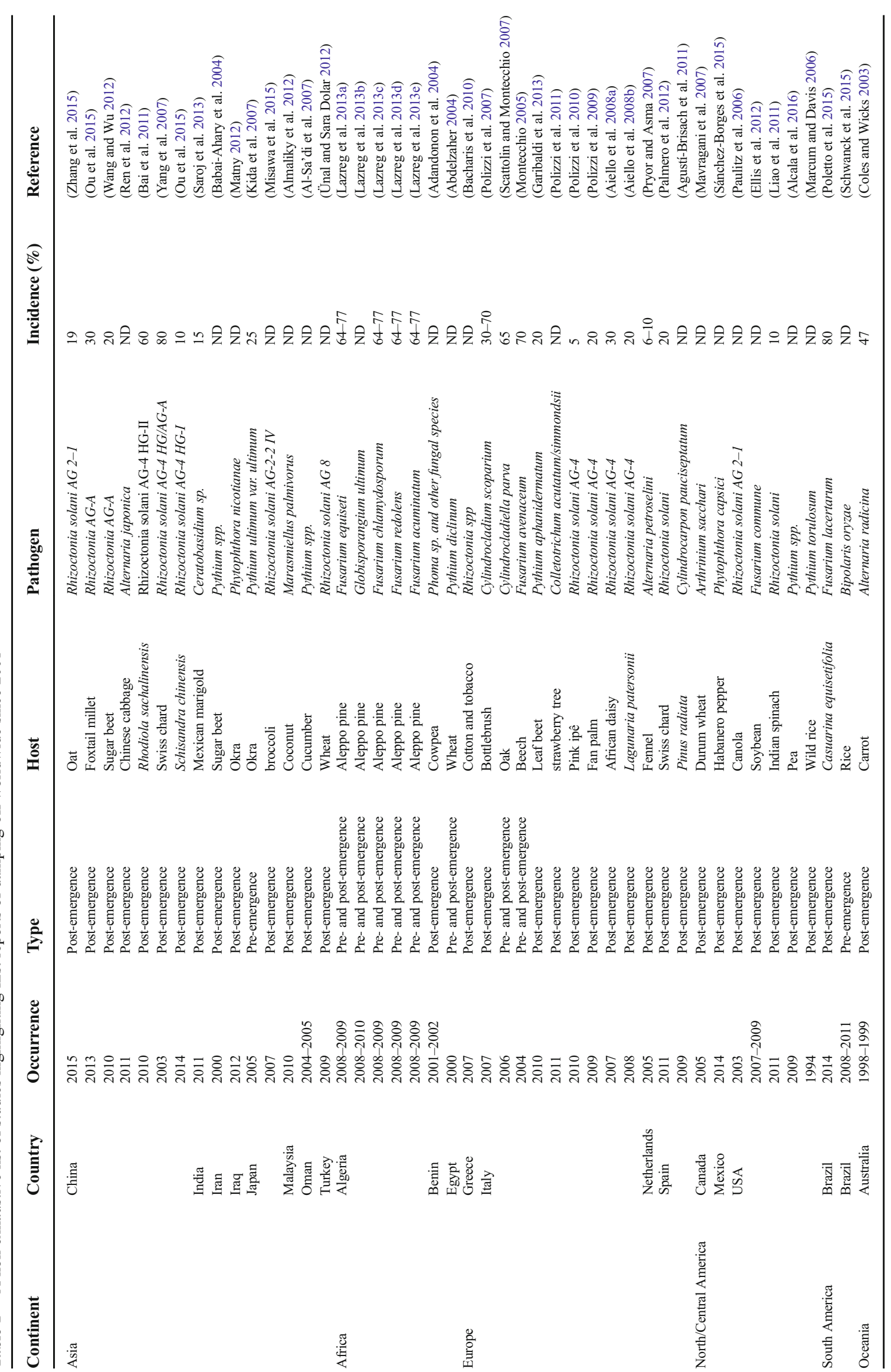


Fig. 2 An overview of soybean (a) and pea (b) fields affected by damping-off diseases due to Pythium spp. The presence of empty space along the row indicates seed or seedlings affected by pre- and postemergence damping-off diseases which killed plants. The economic losses in such a situation are severe owing to a direct cost due to damages of seed or seedlings and an indirect cost related to an additional cost of replanting and the consequent lower yields due to the later planting dates (Fig. 1A is photo courtesy of Martin Chilvers while Fig. 1B is photo courtesy of Lindsey J. du Toit)
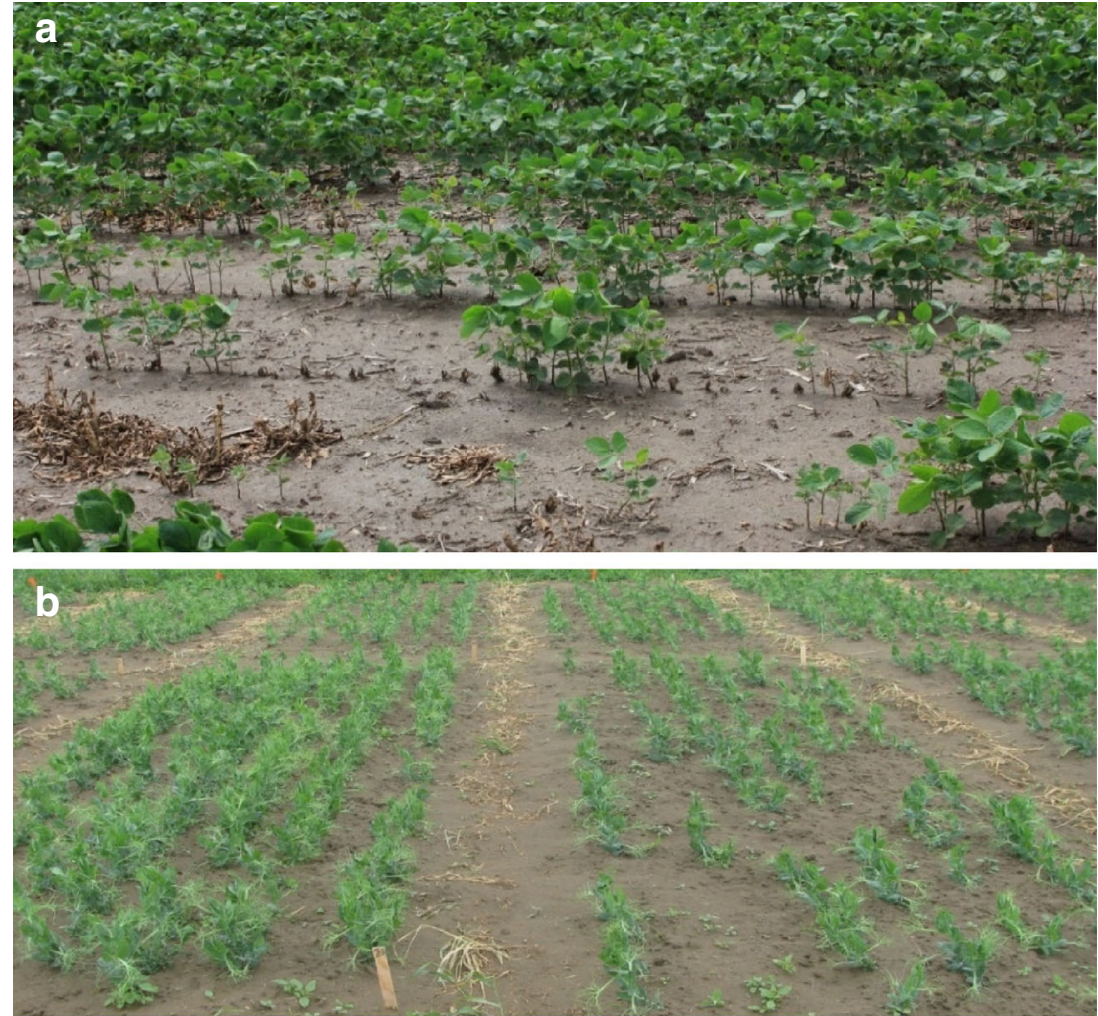

\subsection{Pre-emergence symptoms}

They occur when seeds decay prior to emergence. This can occur (i) before seed germination, or when (ii) the germinating seeds are killed by biotic stresses while shoot tissues are still below ground (Fig. 3; Filer and Peterson 1975; Crous 2002; Horst 2013). In the first case, seeds become soft, rotten, and fail to germinate. In the second case, stems of germinating seeds are affected with characteristic water-soaked lesions formed at or below the soil line (Cram 2003; Landis 2013). With the progression of the disease, these lesions may darken to reddish-brown, brown, or black. Expanding lesions quickly girdle young and tender stems. Seedlings may wilt and die soon before emergence. In general, random pockets of poor seedling emergence are an indication of pre-emergence damping-off.

Abiotic stresses can be divided into two categories: chemical and physical stress. The first notably involves limiting (i) concentrations in carbon dioxide or ethylene (Negm and Smith 1978), (ii) potential of hydrogen (Foy 1984), (iii) osmotic potential (Romo and Haferkamp 1987), and (iv) phytotoxicity (Wang et al. 2001). The second includes (i) extreme temperatures (high or low) (Khan 1977; Wen 2015), extreme seedbed humidity (high or low) (Maraghni et al. 2010; Wen 2015) and (iii) mechanical stresses such as seedbed clods (Dürr and Aubertot 2000), or crusting at the soil surface (Aubertot et al. 2002). Other mechanical events, such as removal of mulch or soil by wind and rain, may also contribute to non-uniform seeding of containers or beds, poor seed development, and seed rot and decay (Landis 2013).

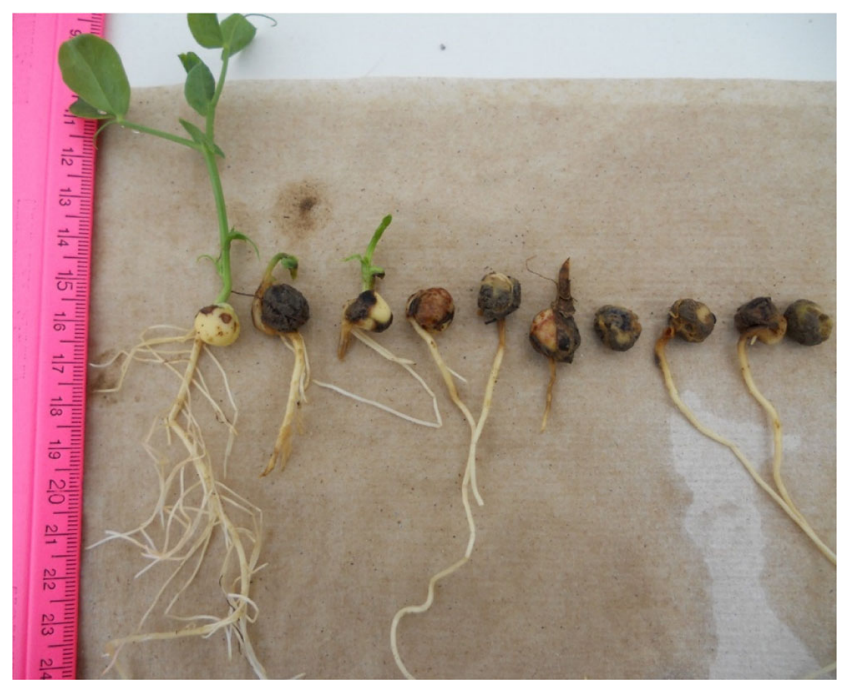

Fig. 3 Characteristic symptoms of pre-emergence damping-off of pea (Pisum sativum L.) caused by Pythium spp. Despite the same sowing date, only the first three seeds on the left have emerged. Note nonemerged seeds with or without root development. Soft, rotten, and decayed seeds prior to germinating or the germinating seeds killed by biotic stresses while shoot tissues are still below ground are characteristic symptoms of pre-emergence damping-off. The sixth seed from the left had germinated but the stem of germinating seeds was affected by the disease with characteristic water-soaked lesions below the soil line. This led to wilting of the seedling soon after emergence (Photo courtesy of Lindsey J. du Toit) 

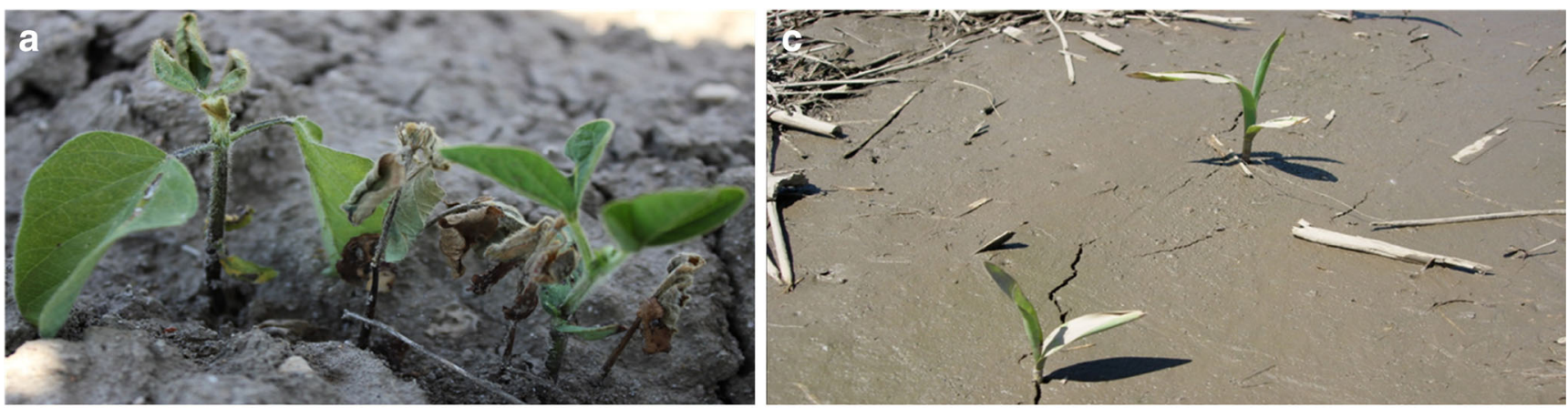

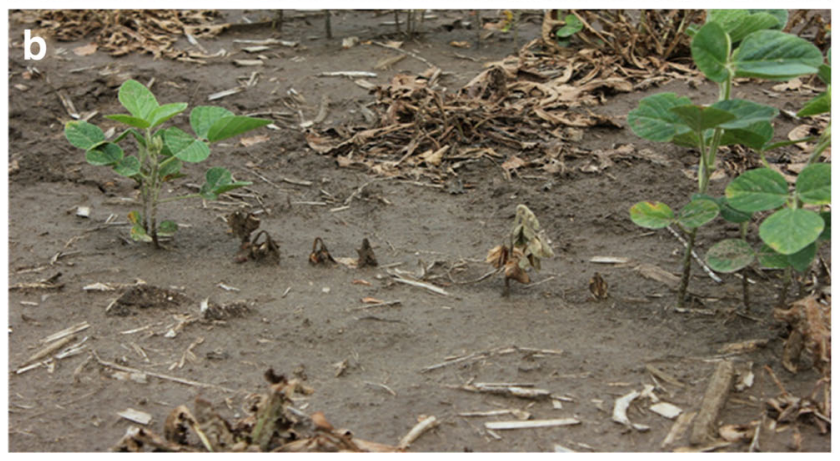

Fig. 4 Characteristic symptoms of post-emergence damping-off of soybean (a and $\mathbf{b}$ ) and corn (c and $\mathbf{d}$ ). The succulent tissue of sprouts with aboveground shoots collapsed, leading to wilting of some seedling populations. Soybean seedlings with stem lesions at ground level and the

Because biotic and abiotic stresses interact among them, it is important to distinguish which of them are associated with the disease symptoms.

\subsection{Post-emergence symptoms}

Post-emergence damping-off symptoms occur when seedlings decay, wilt, and die after emergence (Fig. 4; Boyce 1961; Horst 2013). In most cases, all symptoms result in the collapse and death of at least some seedlings in any given seedling population. In the case of soil-borne pathogen, there could be the death of seedlings in groups in roughly circular patches and the seedlings may have stem lesions at ground level. Seedling stems can become thin and tough (commonly known as "wirestem"), which often leads to reduced seedling vigor. These symptoms can be also accompanied by leaf spotting and a complete root rot may occur. Overall, the symptoms on the stem of the seedlings include water-soaked, sunken lesion at or slightly below the ground level and sometime also below ground line (i.e., on the roots), causing the plant to fall over (Wright 1944; Filer and Peterson 1975). Surviving plants are stunted, and affected areas often show uneven growth.

Abiotic stresses, such as superficial soil heat, can also lead to post-emergence seedling symptoms such as whitish lesions, which are often located only on one side of the stem in the early growth stage of seedlings (Hartley 1918). Such symptoms can be distinguished from those caused by biotic stresses

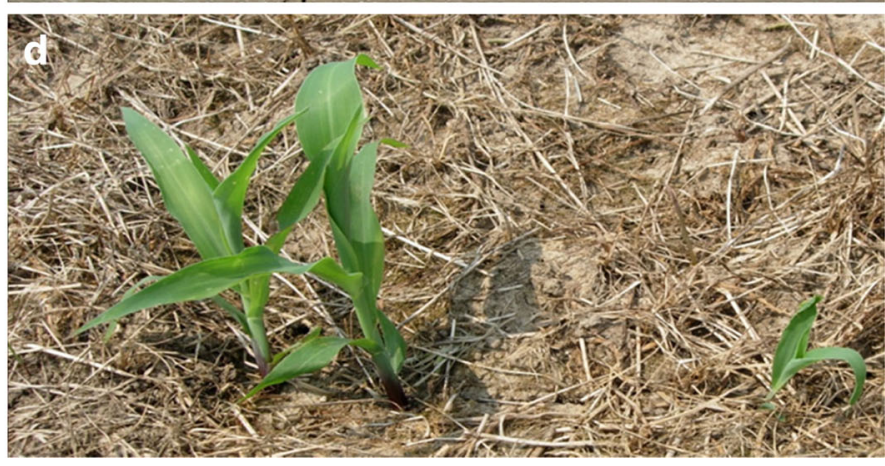

death of seedlings in groups (a and $\mathbf{b}$ ). The presence of an empty space along the row between corn seedlings indicates the lack of emerged seedlings due to damping-off disease (c and d). (Photo courtesy of Martin Chilvers)

because the damage owing to heat lesions is generally scattered throughout nurseries/seedbeds, which mainly depend on patterns of shade and heat buildup (Hartley 1921), while that caused by biotic stresses often occurs in expanding patches. Soil crusting is another important abiotic stress that often hinders seedling emergence or leads to stunted seedling growth (Fig. 5). Phytotoxicity caused by chemical fungicides is another abiotic stress. The symptoms of phytotoxicity, however, may vary based on the type of chemical used including marginal necrosis, chlorotic patches or spots, and malformed flowers, buds, and young leaves (Dole and Wilkins 2004). For example, fungicides based with benzimidazole can cause reduced plant growth and visual damage in bedding plants (Iersel and Bugbee 1996).

\subsection{Occurrence of damping-off symptoms}

Most damping-off diseases present a single sort of symptom (pre- or post-emergence). However, both sorts of symptoms are also reported to some extent (Table 1) although the underlying factors leading to the occurrence of each sort of symptom are poorly discussed in the literature. The complexity of damping-off symptoms result from interactions between cropping practices and the production situation (Aubertot and Robin 2013). This may explain the relevant lack of information. This complexity involves synergism among dampingoff pathogens (Al-Hazmi and Al-Nadary 2015), variation of 


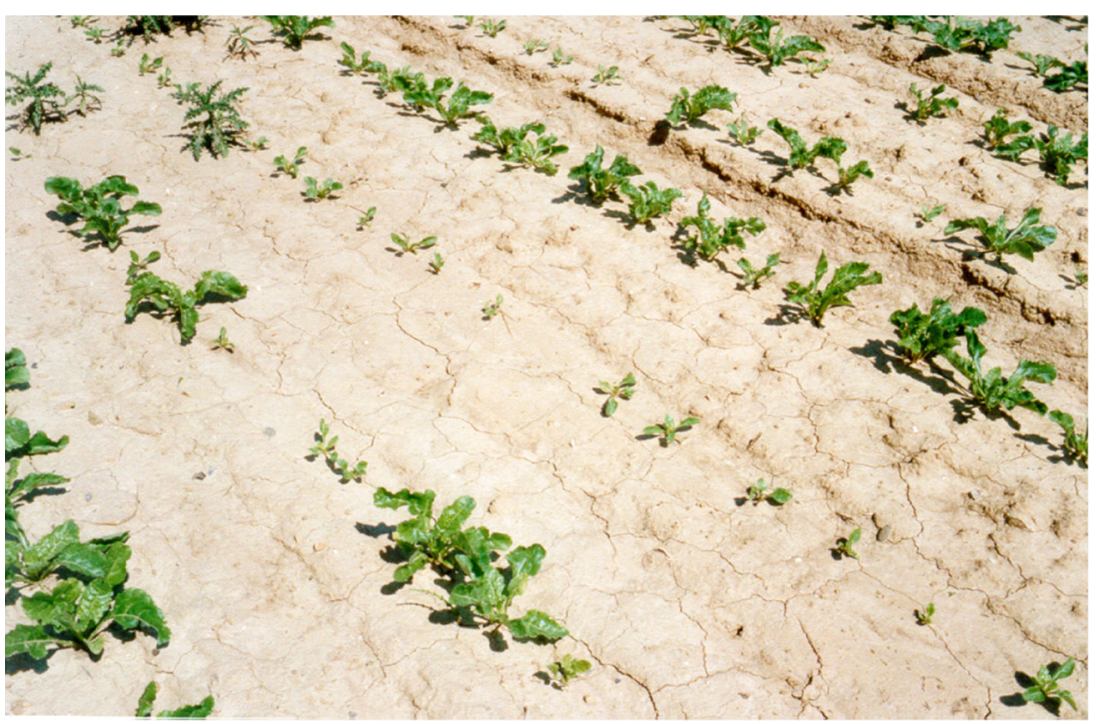

Fig. 5 Lack of sugar beet (Beta vulgaris L.) seedlings emergence due to soil crusting followed by drought. The formation of soil crusts on the soil surface represents a strong mechanical barrier which impedes seedlings from being emerged. Overall, lack of seed germination and emergence in

symptoms according to environmental conduciveness (Schwanck et al. 2015), direct effect of plant density (Burdon and Chilvers 1975), and many other factors, which are very specific for each damping-off symptom. For instance, the disease cycle components of damping-off are seldom discussed in a broader sense in the literature, by comparing different diseases. Some factors related to the time/moment of disease occurrence and timing of disease cycle components could determine whether pre- or post-emergence symptoms will occur. In this sense, it is possible that for both pre- and post-emergence damping-off, the infection occurs during seed germination but a longer or shorter incubation period may implicate in pre- or post-emergence damping-off. In addition, the effect of individual factors involved on the disease processes from the disease cycle and the host cycle (e.g., seed germination), for damping-off symptom development, is rarely discussed in the literature. Taken together, several studies virtually explore the effect of a given factor (e.g., temperature) on damping-off diseases intensity (Ben-Yephet and Nelson 1999), without specifying whether the factor plays a specific role on the pathogen (e.g., organism metabolism) or on the host (e.g., slow germination process increases time exposure underground). Further knowledge on disease cycle features and processes would help better understand damping-off symptom occurrence. Although it was out of the focus of this work, it is worth to mention that from the extensive literature review, we did not perceive any pattern on the sort of damping-off symptom (pre- or post-) according to the region, the pathogen genus, or crop species affected. Therefore, a meta-analytical approach to test hypotheses associated with damping-off diseases would be highly valuable to better explain the factors involved in damping-off symptoms such a field is characteristic of abiotic stresses including stunted growth of seedlings without any necrosis of leaves or stems. (Photo courtesy of Carolyne Dürr)

occurrence. To this aim, the list of damping-off diseases we provide in Table 1 constitutes a potential starting point.

\section{Integrated management of damping-off}

An effective management of damping-off requires the deployment of a number of strategies, which can be classified into the following four major groups: (i) seed treatment to enhance germination and seedling vigor, (ii) deployment of resistant or tolerant cultivars to damping-off diseases, (iii) adoption of best cropping practices, and (iv) timely treatment interventions of seedlings with effective products (conventional pesticides as well as biopesticides and/or biocontrol agents). None of these strategies is effective in managing damping-off disease when applied individually and thus it requires that all of them are combined within the frame of IPM.

\subsection{Seed treatment to enhance germination and seedling vigor}

While the use of completely healthy seeds is the most effective means to prevent and/or contain damping-off diseases, seeds might not be always free from pathogens and thus would benefit from treatments. Even when there is no risk of contaminated seeds from seed-borne pathogens, seed treatments can be an effective means to increase seedling emergence, particularly when done on seeds of low vigor and when the seed coat has been damaged (Mancini and Romanazzi 2014).

Chemical seed treatments still represent a major practice in agriculture to manage damping-off diseases (Rhodes and Myers 1989; Babadoost and Islam 2003; Howell 2007; 
Table 2 Examples of literature reports highlighting the efficacy of non-chemical seed treatments to suppress damping-off diseases. The tested formulations are most often reported to suppress both pre- and post-emergence damping-off although their effectiveness may vary in terms of disease suppressiveness

\begin{tabular}{|c|c|c|c|}
\hline Crop & Pathogen & Formulation/product & Reference \\
\hline Alfalfa & Pythium spp. & Mineral seed coating & (Samac et al. 2014) \\
\hline Canola & Pythium spp. & Rhizosphere bacteria & (Bardin et al. 2003) \\
\hline Corn & Pythium and Fusarium spp & Several biocontrol agents & (Mao et al. 1997; Mao et al. 1998) \\
\hline Cotton & Pythium spp. & $\begin{array}{l}\text { Enterobacter cloacae and } \\
\quad \text { Erwinia herbicola }\end{array}$ & (Nelson 1988) \\
\hline Cotton & Pythium spp., Rhizopus oryzae & Trichoderma spp. & (Howell 2007) \\
\hline Cucumber & Pythium ultimum & $\begin{array}{l}\text { Ethanol extracts of Serratia } \\
\text { marcescens and Trichoderma spp. }\end{array}$ & (Roberts et al. 2016) \\
\hline Cucumber & Pythium spp. & Phosphonate & $\begin{array}{l}\text { (Abbasi and Lazarovits 2005; Abbasi and } \\
\text { Lazarovits 2006) }\end{array}$ \\
\hline Sunflower & Rhizoctonia solani & Spermine & (El-Metwally and Sakr 2010) \\
\hline $\begin{array}{l}\text { Lentil, pea, } \\
\text { sugar beet }\end{array}$ & Pythium spp. & Rhizobium leguminosarum & (Bardin et al. 2004b; Huang and Erickson 2007) \\
\hline Pea & Pythium spp. & Rhizosphere bacteria & (Bardin et al. 2003) \\
\hline Safflower & Pythium spp. & Rhizosphere bacteria & (Bardin et al. 2003) \\
\hline Sesame & Soil-borne pathogens & Paenibacillus polymyxa & (Ryu et al. 2006) \\
\hline Sugar beet & Pythium spp. & Rhizosphere bacteria, crop straw powders & (Bardin et al. 2003; Bardin et al. 2004a) \\
\hline Tomato and hot pepper & Pythium spp. & Fluorescent Pseudomonads & (Ramamoorthy et al. 2002) \\
\hline
\end{tabular}

Bradley 2007; Leisso et al. 2009; Dorrance et al. 2009; Rothrock et al. 2012; Kandel et al. 2016). Several chemicals including bleach, hydrogen peroxide, ethanol, and fungicides can be applied to remove pathogen inoculum from seed coats (Dumroese and James 2005; Mancini and Romanazzi 2014). Generally, chemical treatments are effective but they can also negatively affect seed germination and cause phytotoxicity (Axelrood et al. 1995; du Toit 2004) besides negative impacts to human health and the environment (Lamichhane et al. 2016). In addition to chemical treatments, physical seed treatment can be applied including hot water, hot air, and electron treatments (Mancini and Romanazzi 2014). Finally, a number of biological seed treatment methods are being developed and used in recent years with a satisfactory level of damping-off disease suppression (Table 2).

Because seed germination and emergence are often influenced by site-specific soil and climate conditions, an in-depth knowledge of a specific site in question is a prerequisite for an effective decision-making process for seed treatments. An experiment on pesticide-free agroecosystems conducted in 2014 across eight experimental sites in France, with non-treated seeds, showed that the percentage of emergence rates markedly differs for the same seeds across the sites (Fig. 3). In particular, while the rate of emergence of soft wheat was $100 \%$ in the Le Rheu and Grignon sites, it was lower across other sites ranging from $43 \%$ in Auzeville to $75 \%$ in Lusignan (Fig. 6). This means that while seed treatments may result essential across some sites, due to unfavorable soil and climatic conditions, which are conducive to disease development, it may not be the case in other areas.

\subsection{Deployment of host-plant resistance and/or tolerance}

Overall, host-plant resistance as a management tactic is composed of the following two strategies: (i) deployment of resistant and/or tolerant plant varieties, which support lower pathogen populations or better tolerate injury caused by them; and (ii) the integration of such varieties with other management tactics within the frame of IPM. Unfortunately, for many plant pathogens, including those causing damping-off diseases, no plant cultivar with measurable resistance is available (Babadoost and Islam 2003). Therefore, the only way to better use the available crop varieties with tolerance to pathogens is through their adequate integration with other disease management measures. Nevertheless, insufficient focus has been paid to date to the integration of plant resistance with other IPM tactics, and to quantifying the benefits of plant resistance in multi-tactic IPM programs (Stout and Davis 2009).

On the other hand, the breeding approach used to date to develop resistant and/or tolerant crop varieties should be revisited if we want to focus on sustainable crop protection based on IPM. This is particularly true taking into account the fact that most, if not all, crop varieties bred to date are based on a market-driven approach focused on high-yielding and most profitable crop varieties. This trend has boosted adoption of short rotations or monoculture practices, on one hand, and ignored the potential that minor crops may have for IPM, on the other (Messéan et al. 2016). The limited range of available minor crop varieties has been reported as one of the major obstacles to crop diversification, thereby confining certain beneficial practices such as multiple cropping or intercropping (Enjalbert et al. 2016; Messéan et al. 2016). Therefore, breeding for IPM should be based on a different approach than the 


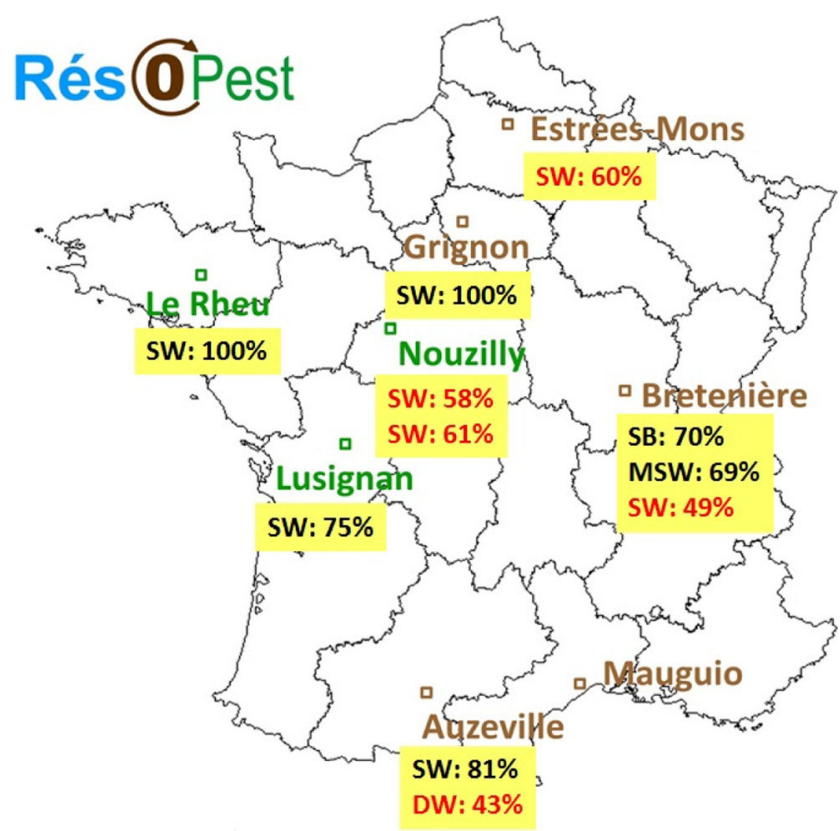

Fig. 6 Percentage of seed emergence (non-treated seeds) observed across different experimental sites managed under the "Res0Pest" network in France in 2014. Res0Pest is a "pesticide-free" trial network launched in 2011 by the INRA/CIRAD IPM network to address objectives of the French National Action Plan Ecophyto to develop and demonstrate the feasibility of pesticide-free cropping systems (Deytieux et al. 2014). Eight experimental sites, comprised of five arable cropping systems (in brown) and three mixed crop/husbandry systems (in green) are ongoing across the sites. $D W$ durum wheat, $S W$ soft wheat, $M S W$ mixed of soft wheat varieties, $S B$ spring barley. Different percentages of emergence across the experimental sites highlight how soil and climate and cropping practices affect seed germination and the seedling emergence process through biotic and abiotic stress. Low percentages of emerged seedlings are highlighted in red

traditional one given the strategic role of breeding in the competitiveness of crops and their adaptation to more diversified cropping systems (Enjalbert et al. 2016).

\subsection{Adoption of best cropping practices}

Once the causal agent of damping-off has been identified, all available cropping practices could be adapted to discourage the development of the pathogen. Indeed, any technique that allows to reduce the time between seed germination and emergence helps reduce effects of biotic stresses on seedlings. Overall, many pathogens involved in damping-off are relatively weak pathogens, which require favorable environmental conditions for infection to occur (Table 1). In addition to the susceptibility of host and aggressiveness of pathogen populations, the severity of damping-off is highly dependent on some critical factors including seedbed preparation, soil $\mathrm{pH}$ management, seeding date and rate, growing density, nutrition, irrigation, growing environment, crop sequence and intercropping, cover crops, soil residue management, soil solarization, and tillage (Table 3). Therefore, understanding combined effects of abiotic and biotic stresses and factors influencing them are a prerequisite towards effective IPM strategies of damping-off. Once these critical factors have been identified, which might differ from one region to another, best cropping practices should be put in place and adopted.

One of the most important practices that allow to the best management of damping-off and root diseases is fertilization. Adequate availability of nutrients in the soil can ensure higher vigor, with earlier emergence that limit the period of time where pathogens can infect seeds and seedlings during the autotrophic stage. In particular, the advantages of fertilizer placement on seed germination and seedling emergence have been previously demonstrated (Cook et al. 2000). The placement of fertilizers, directly under or slightly to one side of the seed, at the time of planting or sowing results in an increased level of seed germination and emergence (Fig. 7). This is because relatively immobile nutrients, such as phosphorus, are not readily available for plants especially for those species having no or a few lateral roots. Therefore, field fertilization, where damping-off diseases are important, requires that the nutrients be made easily accessible to the roots to increase growth rate. Although these nutrients do not always reduce seedling infection, they often enhance seed germination and seedling vigor (Smiley et al. 1990; Patterson et al. 1998). Indeed, higher seedling vigor allows seedlings to rapidly escape from the soil surface even in the presence of a high soil population density of the pathogen(s).

\subsection{Timely treatment interventions of seedlings with effective products}

The strategies described above are mainly of preventive nature as they can be developed and adopted before the occurrence of damping-off diseases. Once the infection occurs on seedlings and there is a high risk of epidemic development, growers have to attempt for an effective control of the disease. Overall, there are two key measures available for dampingoff control as described below.

\subsubsection{Biological control}

Because of their adverse effects on human health and the environment, the use of conventional pesticides, including fungicides, has come under increasing public scrutiny in many countries especially in the European Union (Bourguet and Guillemaud 2016; Lamichhane et al. 2016). In addition, increasing reports of pest resistance 
Table 3 Critical factors affecting damping-off and best cropping practices which help discourage its development

\begin{tabular}{|c|c|c|}
\hline Critical factors & Best cropping practices & References \\
\hline Seed quality & $\begin{array}{l}\text { Use of clean, healthy, and sterile seeds, treatments with } \\
\text { non-chemical products including beneficial microbes to } \\
\text { enhance seed health and resilience and to promote rapid } \\
\text { germination and emergence and control pre-emergence } \\
\text { damping-off, and chemical treatment to control } \\
\text { post-emergence damping-off }\end{array}$ & $\begin{array}{l}\text { (Mao et al. 1998; Babadoost and Islam 2003; Jensen } \\
\text { et al. 2004; Abbasi and Lazarovits 2006; Howell } \\
\text { 2007; Gwinn et al. 2010; Mastouri et al. 2010; } \\
\text { Samac et al. 2014; Roberts et al. 2016) }\end{array}$ \\
\hline Seedbed preparation & $\begin{array}{l}\text { Utilize pest-free soil or growing medium through incorporation of } \\
\text { compost, plant residues, or microbial amendments into soil or } \\
\text { growing medium which suppress soil-borne pathogens, } \\
\text { perform soil solarization, bio-fumigation, adopt mixture of } \\
\text { particle sizes and good porosity to avoid soil crusting, improve } \\
\text { soil drainage by subsoiling, crowning the beds, installing } \\
\text { drainage tiles, and incorporating composted organic matter to } \\
\text { improve soil texture, water-holding capacity, nutrient } \\
\text { availability, and cation exchange capacity }\end{array}$ & $\begin{array}{l}\text { (Kassaby 1985; Ben-Yephet and Nelson 1999; Dürr and } \\
\text { Aubertot 2000; Diab et al. 2003; Deadman et al. } \\
\text { 2006; Njoroge et al. 2008; Pane et al. 2011; He et al. } \\
\text { 2011; Landis 2013; Bahramisharif et al. 2013a; } \\
\text { Vitale et al. 2013) }\end{array}$ \\
\hline Adjustment of soil $\mathrm{pH}$ & $\begin{array}{l}\text { Use relatively acidic soils with a low } \mathrm{pH}(4.5-6.0) \text {, increase soil } \\
\mathrm{pH} \text { with organic amendments, with applications of aluminum } \\
\text { sulfate, sulfur, or acid peat }\end{array}$ & (Russell 1990; Davey 1996; Cram 2003) \\
\hline Seeding date & $\begin{array}{l}\text { Perform sowing neither too early nor too late, avoid warm or wet } \\
\text { weather for sowing, well irrigate soils to the depth of the } \\
\text { growing roots without flooding the soil }\end{array}$ & (Hwang et al. 2000; Cram 2003) \\
\hline Growing density & $\begin{array}{l}\text { Avoid over-sowing or excessive plant densities, use crop varieties } \\
\text { with asynchronous germination }\end{array}$ & $\begin{array}{l}\text { (Burdon and Chilvers 1975; Neher et al. 1987; Landis } \\
\text { 2013) }\end{array}$ \\
\hline Nutrition & $\begin{array}{l}\text { Apply well-balanced fertilization especially microelements } \\
\text { (phosphorus, potassium, and calcium) }\end{array}$ & $\begin{array}{l}\text { (Gladstone and Moorman 1989; James 1997; } \\
\text { El-Metwally and Sakr 2010; Landis 2013) }\end{array}$ \\
\hline Growing environment & $\begin{array}{l}\text { Maintain moderate humidity, escape application of high water } \\
\text { volume to avoid waterlogging and adopt frequent and light } \\
\text { applications, maintain adequate light and optimal temperatures }\end{array}$ & $\begin{array}{l}\text { (Beech 1949; Duniway 1983b; Wong et al. 1984; } \\
\text { Yitbarek et al. 1988; Hwang et al. 2000; Schmidt } \\
\text { et al. 2004; Kiyumi 2009; Landis 2013; Li et al. } \\
\text { 2014) }\end{array}$ \\
\hline $\begin{array}{l}\text { Crop sequence and } \\
\text { intercropping }\end{array}$ & $\begin{array}{l}\text { Avoid monoculture and adopt long rotation schemes to lower } \\
\text { down pathogen populations, introduce Brassica crops as their } \\
\text { root exudates contain soil-borne pathogen populations }\end{array}$ & $\begin{array}{l}\text { (Hwang et al. 2008; Abdel-Monaim and Abo-Elyousr } \\
\text { 2012) }\end{array}$ \\
\hline $\begin{array}{l}\text { Cover crops and soil residue } \\
\text { management }\end{array}$ & $\begin{array}{l}\text { While cover crops are overall useful to produce organic matters } \\
\text { and protect the soil from erosion and leaching, their benefit can } \\
\text { vary with the type of species selected. Certain leguminous } \\
\text { cover crops even favor greater populations of damping-off } \\
\text { pathogens than graminaceous plants }\end{array}$ & $\begin{array}{l}\text { (Hansen et al. 1990; Russell 1990; Davey 1996; Bailey } \\
\text { and Lazarovits 2003) }\end{array}$ \\
\hline Tillage & $\begin{array}{l}\text { Perform tillage to incorporate plant residues into the soil to reduce } \\
\text { soil-borne pathogen populations although the effect of tillage } \\
\text { may differ from the type of pathogen to be managed }\end{array}$ & $\begin{array}{l}\text { (Tachibana 1983; Workneh et al. 1998; Bailey and } \\
\text { Lazarovits 2003) }\end{array}$ \\
\hline
\end{tabular}

development to pesticides have become an issue, thereby increasing risks of pest management failure with potential threats of economic losses for farmers (Onstad 2013; Bourguet and Guillemaud 2016; Lamichhane et al. 2016). Chemical fungicides can also cause phytotoxicity on crops and foliage plants, which is another drawback of their use (Dias 2012).

The application of biocontrol agents/formulations is an important substitute to conventional fungicides, with lower negative impacts. Often, biocontrol is widely practiced as an alternative disease management strategy to conventional fungicides especially when the latter are not effective or cause secondary problems such as seed phytotoxicity from fungicides (Burns and Benson 2000). Individual beneficial organisms used as biocontrol agents can prevent damping-off pathogens through five mechanisms (Table 4). There are dozens of biocontrol products to control damping-off worldwide and most of them are based on antagonist fungi, including Trichoderma spp. and Gliocladium spp. or bacteria such as Pseudomonas spp. and Bacillus spp. (Table 5). However, not all of them are registered and marketed as biocontrol agents nor they are used as plant growth promoters, plant strengtheners (or biostimulants), or soil conditioners (Paulitz and Bélanger 2001). Numerous studies conducted on biocontrol research in the last 15 years clearly suggest the increasing concern of the scientific community to generate knowledge on an alternative to chemical solutions (Table 5). Most of these studies have also demonstrated a good effectiveness of biocontrol products in managing the disease. Accordingly, the biocontrol industry has become very dynamic in recent years especially in terms of using the available scientific knowledge to develop and 


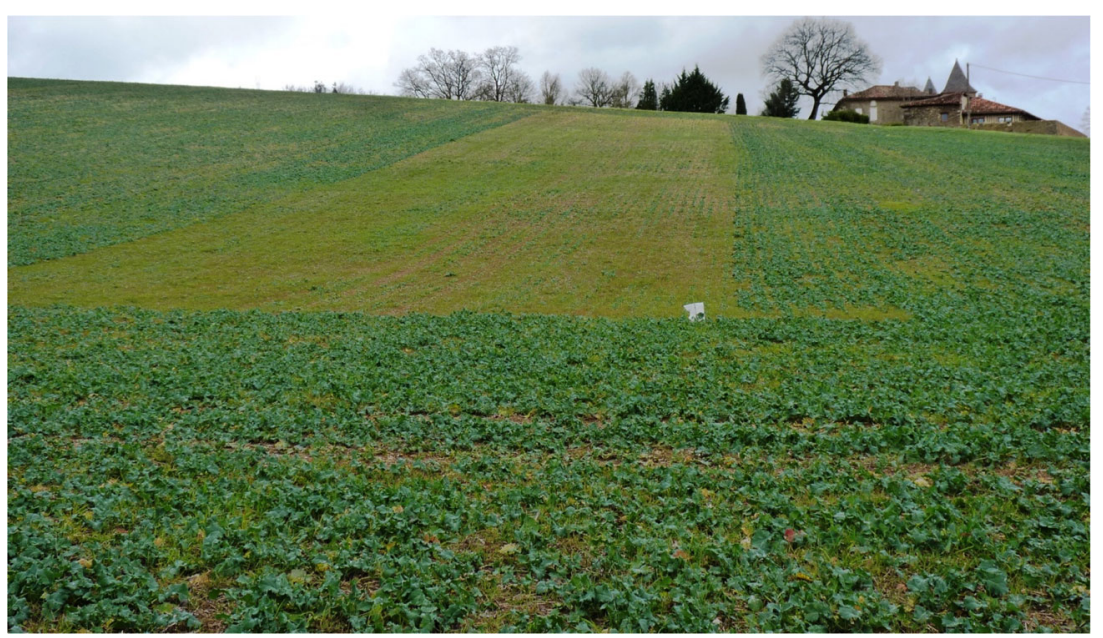

Fig. 7 Effect of fertilizer placement on germination and emergence of oilseed rape. While the placement of micronutrients (zinc and phosphorous) at the time of sowing allowed seeds to readily germinate and emerge (the three lateral sides of the plot), the lack of nutrient placement has resulted in markedly reduced seed germination and

commercialize formulations. However, most of these formulations are based on individual biocontrol agents and they specifically target a specific pathogen.

\subsubsection{Chemical control}

While alternative tactics to chemical control are the priority for IPM to manage damping-off diseases, such measures available on the market are not always effective in controlling damping-off diseases and/or their effectiveness is variable. Therefore, a judicious use of fungicides maybe needed to combine with other IPM tactics especially when the disease infection has already occurred (Harman 2000).

Chemical control of damping-off as foliar application, however, is restricted to a few active ingredients due to the high cost of fungicides and the small number of products registered for some crops including those for ornamental use (Garzón et al. 2011). Among the most frequently used fungicides, there are etridiazole and metalaxyl, active against Phytopthora and Pythium spp.; benomyl and thiophanate methyl, active against Fusarium and Rhizoctonia spp.; mancozeb and maneb, active against Fusarium and Phythium spp.; and captan, active against common damping-off pathogens. A rapid decrease in market availability of many previously available fungicides further limits access to chemical treatments in many countries especially in the European Union (Lamichhane et al. 2016). On the other hand, resistance to commonly used fungicides developed by several strains of pathogens has challenged the long-term sustainability of chemical control (Taylor et al. 2002; Allain-Boulé et al. 2004; Moorman and Kim 2004; Reeleder et al. 2007; Weiland et al. 2014). All these new scenarios clearly highlight that nonchemical measures will be increasingly developed and used emergence (the middle of the plot). The same field practices were applied in the field, including the same date of sowing and cultivar. In addition to oilseed rape, the cultivated field presents annual weed $P o a$ annua and Vulpia myuros (light green color). (Photo courtesy of JeanPierre Sarthou)

for the management of damping-off, particularly for postemergence ones. This trend is clear also in the literature where most recent research efforts are on the development of biocontrol solutions rather than focusing on the chemical ones (Tables 2 and 5). This happens due to the general concerns with regards to conventional pesticides, but also because private and public sectors can design new solutions for the socalled "biocontrol market." However, even with biocontrol solutions, diagnosis of the involved pathogens along with the analysis of treatment opportunity is still required.

\section{Key challenges and future priorities for damping-off management}

In order to tackle the complex and multifaceted nature of damping-off diseases and a range of factors that affect their occurrence and development, we propose five research priorities, which are essential towards a better understanding and management of damping-off diseases.

\subsection{Correct identification of damping-off pathogens including non-secondary colonizers and anastomosis groups}

An accurate identification of the causal agent(s) associated with damping-off is imperative for understanding the etiology of damping-off outbreaks and thus represents a cornerstone for the decision-making process to IPM. This involves confirming the pest, learning how it spreads, and then identifying critical points for its management, including development of preventive measures based on adapted cropping practices. Most often, the specific pathogen causing damping-off 
Table 4 Key mechanisms involved in biocontrol activities and list of selected references

\begin{tabular}{|c|c|c|}
\hline Mechanism & Description & References \\
\hline Antibiosis & $\begin{array}{l}\text { A biocontrol microorganism produces antibiotics which is toxic to one or } \\
\text { more pathogens }\end{array}$ & $\begin{array}{l}\text { (Shang et al. 1999; Wright et al. 2001; Koumoutsi et al. 2004; } \\
\text { Kloepper et al. 2004; Islam et al. 2005; Leclere et al. 2005; } \\
\text { Pal and McSpadden 2006; Gerbore et al. 2014) }\end{array}$ \\
\hline Parasitism & $\begin{array}{l}\text { A biocontrol organism parasitizes one or more pathogens. This is a typical } \\
\text { example of Trichoderma spp. which winds around the hyphae of } \\
\text { soil-borne fungi and oomycetes by puncturing their cell wall }\end{array}$ & $\begin{array}{l}\text { (Benhamou and Chet 1997; Kiss 2003; Milgroom and Cortesi } \\
\text { 2004; Pal and McSpadden 2006; Gerbore et al. 2014) }\end{array}$ \\
\hline Competition for nutrients & $\begin{array}{l}\text { A biocontrol organism produces and releases many substances that have } \\
\text { suppressive effects towards pathogens. This help a biocontrol agent to } \\
\text { effectively colonize plant environments }\end{array}$ & $\begin{array}{l}\text { (van Dijk and Nelson 2000; Kageyama and Nelson 2003; Pal } \\
\text { and McSpadden 2006; Liu et al. 2013; Gerbore et al. 2014) }\end{array}$ \\
\hline $\begin{array}{l}\text { Production of lytic enzymes or other } \\
\text { chemical signals }\end{array}$ & $\begin{array}{l}\text { A biocontrol organism produces metabolites that can interfere with } \\
\text { pathogen growth and/or activities via degradation of essential } \\
\text { compounds needed for soil-borne pathogens to develop and start the } \\
\text { infection process }\end{array}$ & $\begin{array}{l}\text { (Bull et al. 2002; Kilic-Ekici and Yuen 2003; Benhamou 2004; } \\
\text { Palumbo et al. 2005; de los Santos-Villalobos et al. 2013; } \\
\text { Gerbore et al. 2014) }\end{array}$ \\
\hline Induced systemic resistance (ISR) & $\begin{array}{l}\text { A beneficial organism stimulates the plant's immune system thereby } \\
\text { protecting plants from pathogens. ISR is a different mechanism from } \\
\text { systemic acquired resistance (SAR). The latter occurs following an } \\
\text { exposition of a plant to a low level of a specific pathogen which allows } \\
\text { plants to acquire resistance to that specific pathogen in the future }\end{array}$ & $\begin{array}{l}\text { (Chen et al. 2000; Hammond-Kosack and Jones 2000; } \\
\text { Bargabus et al. 2002; Bargabus et al. 2004; Ongena et al. } \\
\text { 2004; Kloepper et al. 2004; Meziane et al. 2005; Pal and } \\
\text { McSpadden 2006; Gerbore et al. 2014; Pieterse et al. 2014) }\end{array}$ \\
\hline
\end{tabular}

cannot be determined based on the visual inspections of symptoms. Therefore, their correct identification is essential. It is generally performed using both culture-based and cultureindependent methods. However, both of these techniques have their advantages and drawbacks and hence are complementary to each other. For example, culture-based techniques allow for the characterization of important traits such as virulence or fungicide resistance. Not only are they time consuming, but they also underestimate the true diversity of species present within a sample (Zinger et al. 2012; James 2012b; Bik et al. 2016). Culture-independent methods, such as next generation sequencing, on the other hand, allow to identify the overall species diversity present in a given sample but their limit is that they do not allow to determine the virulence and fungicide resistance of the microbes associated with the disease (Lamichhane and Venturi 2015).

Although many modern PCR techniques allow a rapid detection and identification of one or more specific pathogens,

Table 5 List of selected studies reporting the use of microbial antagonists for biological control of major damping-off pathogens worldwide since 2001. These biological control agents were either applied to seedlings or to soil to achieve disease suppression

\begin{tabular}{|c|c|c|c|}
\hline Pathogen(s) & Host & Biological control agent(s) & References \\
\hline Pythium spp. & Tomato & Different bacteria & (Gravel et al. 2005) \\
\hline Pythium aphanidermatum & Cucumber & $\begin{array}{l}\text { Paenibacillus spp. with organic compounds; } \\
\text { Streptomyces griseoviridis, Trichoderma spp., } \\
\text { Gliocladium catenulatum }\end{array}$ & (Punja and Yip 2003; Li et al. 2011) \\
\hline Pythium aphanidermatum & Tomato & Trichoderma harzianumstrain & (Jayaraj et al. 2006) \\
\hline Pythium ultimum & Cucumber & Different bacterial and fungal isolates & $\begin{array}{l}\text { (Georgakopoulos et al. 2002; Carisse } \\
\text { et al. 2003) }\end{array}$ \\
\hline $\begin{array}{l}\text { Pythium ultimum and } \\
\text { Rhizoctonia solani }\end{array}$ & Bedding plants & Gliocladium catenulatum & (Mcquilken et al. 2001) \\
\hline Rhizoctonia spp. & Chinese mustard & Endomycorrhizal Rhizoctonia & (Jiang et al. 2015) \\
\hline Rhizoctonia solani & Cucumber & $\begin{array}{l}\text { Bacillus pumilus SQR-N43; Glomus mosseae and } \\
\text { plant growth-promoting fungi; Paenibacillus } \\
\text { illinoisensis }\end{array}$ & $\begin{array}{l}\text { (Jung et al. 2003; Chandanie et al. } \\
\text { 2009; Huang et al. 2012) }\end{array}$ \\
\hline Rhizoctonia solani & Pepper & Fluorescent pseudomonads with resistance inducers & (Rajkumar et al. 2008) \\
\hline Rhizoctonia solani & Radish & Peony root bark with Trichoderma harzianum & (Lee et al. 2008) \\
\hline Rhizoctonia solani & Tomato & Streptomyces & (Sabaratnam and Traquair 2002) \\
\hline Rhizoctonia solani & Different crops & Trichoderma spp. & (Lewis and Lumsden 2001) \\
\hline $\begin{array}{l}\text { Rhizoctonia solani and } \\
\text { Fusarium solani }\end{array}$ & Tomato & Olive mill waste water and its indigenous bacteria & (Yangui et al. 2008) \\
\hline Rhizoctonia spp. & Cotton & Nonpathogenic Binucleate Rhizoctonia spp. & (Jabaji-Hare and Neate 2005) \\
\hline Several soil-borne pathogens & Cucumber & Several antagonist bacteria & (Roberts et al. 2005) \\
\hline
\end{tabular}


including those reported to cause damping-off diseases (Weiland and Sundsbak 2000; Lievens et al. 2006; Ishiguro et al. 2013), the timely identification of the overall species diversity involved in the disease occurrence process still remains a challenge. In addition, such techniques require DNA purification, the availability of more expensive and sophisticated equipment, and more highly trained technical personnel to perform the test (Schroeder et al. 2012), which is a strong limit to their wider adoption. Therefore, we still need to develop techniques, which could simplify the detection, on one hand, and be economically sustainable, on the other.

All four soil-borne pathogens dealt in this paper are characterized by a complex of genetically distinct species, with a wide host range or virulence preference for certain hosts. For example, Rhizoctonia solani species Kühn (teleomorph: Thanatephorus cucumeris; A. B. Frank; Donk) is a multinucleate species that has been divided into 14 anastomosis groups (AGs; AG1 to AG13 and AG B1; (Sneh et al. 1991; Carling and Summer 1992; Carling et al. 2002). Binucleate Rhizoctonia spp. (teleomorph: Ceratobasidium) are divided into 19 AGs (AG A to AG S). Finally, R. oryzae and R. zeae are multinucleate with the teleomorphs Waitea circinata var. circinata and W. circinata var zeae, respectively (Sneh et al. 1991). Given its variable nature within- and between-AG variation in virulence and host range, a correct and timely identification of the specific genetic lines associated with damping-off diseases is still a challenge, which calls for further research efforts.

Fusarium spp. are characterized by a wide genetic diversity and their taxonomy has been afflicted by changing species concepts, with as few as 9 to over 1000 species being recognized by different taxonomists during the past 100 years (Summerell et al. 2003). Indeed, the complexity and the recognized difficulty of rapidly identifying cultures to species have been reported as the major reason hindering effective disease management (Summerell et al. 2003). The challenge within the Fusarium species complex is also to determine the specific role of secondary colonizers in occurrence and development of damping-off diseases since they are characterized by a high variability and complexity in terms of host range and virulence.

Similar problems exist also for Pythium species with most plant-pathogenic lines having a wide host range. For example, Pythium ultimum is reported to attack over 719 host plants (Farr and Rossman 2012). Other species such as Pythium graminicola and Pythium arrhenomanes are restricted only to Poaceae family (Schroeder et al. 2012). Traditional baiting or other culture-based techniques are still widely used for the identification of Pythium species although cultureindependent methods, such as cytochrome oxidase subunit 1 pyrosequencing, are also used (Coffua et al. 2016). The challenge is that methodological biases inherent to culture- independent methods may often lead to inconsistencies in diversity estimates of Pythium species associated with dampingoff diseases. Nevertheless, culture-based techniques are the only means to demonstrate, for example, the presence of potential pathogens even in fields with no previous history of damping-off diseases. Indeed, based on culture-based techniques, several studies have isolated Pythium species from symptomatic and asymptomatic plants and demonstrated their pathogenicity on a large number of plant species (Bahramisharif et al. 2013b; Coffua et al. 2016). Further, culture-based methods and morphological observations may still result essential in confirming the presence of novel or unexpected species within a sampling location and thus have to be considered for identification purposes (Zitnick-Anderson and Nelson 2014).

The complexity in terms of taxonomy is even more accentuated for the genus Phytophthora with many studies over recent years recognizing different Phytophthora as a species complex. Often, the taxonomic status of the related species is also a matter of controversy or the presence of several distinct lineages perhaps representing as yet undescribed species (Safaiefarahani et al. 2015). Many new species of Phytophthora are constantly proposed and the taxonomy of this genus has been evolving very dynamically (Henricot et al. 2014). Consequently, development of rapid and reliable diagnostic methods is a challenging task for this genus too.

Because most damping-off pathogens are either soilor water-borne, instead of airborne, adoption of good phytosanitary practices generally allows to manage damping-off diseases. This is especially the case if a proper detection of the causal agent(s) is timely made. This helps understand also critical management points that allow pathogens to enter into the field and/or nursery. The mode of transmission maybe different for each pathogen although spread in infected soil or growing medium is common to all species (Table 6). Because most of these pathogens are common in agricultural soils, they can be spread via contaminated soil, introduction of infected plants (mainly in case of seed-borne pathogens), improperly sanitized equipment and greenhouse, and the use of contaminated irrigation water (Zappia et al. 2014). In particular, Pythium spp. and Phytophthora spp. have motile zoospores, which are most commonly spread by water leading to epidemic developments (Hong and Moorman 2005; Zappia et al. 2014). Therefore, the potential presence of these pathogens in irrigation water should be timely determined using appropriate bioassays such as in-situ baiting (Ghimire et al. 2009) or PCR techniques (Martin et al. 2012; Schroeder et al. 2012). Appropriate treatments of the water should be implemented if their presence is confirmed in irrigation water. Detection and management approaches of plant pathogens in irrigation water have 
Table 6 Mode of transmission of major causal agents of damping-off and soild and climate conditions favorable to their development. Any IPM approach should consist in the adoption of cropping practices, including cultivar choice and chemical control which could discourage factors favoring damping-off

\begin{tabular}{|c|c|c|c|}
\hline Pathogen & Mode of transmission & Optimal pedo-climatic conditions for damping-off & References \\
\hline Pythium spp. & Irrigation water, soil & $\begin{array}{l}\text { High soil moisture, } \mathrm{pH}>5.8 \text {, the effect of temperature } \\
\text { is variable based on the type of damping-off. While } \\
\text { pre-emergence damping-off may occur at low } \\
\text { temperatures }\left(12^{\circ} \mathrm{C}\right) \text {, the post-emergence one } \\
\text { is favored by relatively high temperature }\left(18 \text { to } 30^{\circ} \mathrm{C}\right)\end{array}$ & $\begin{array}{l}\text { (Roth and Riker 1943; Leach 1947; } \\
\text { Wright 1957) }\end{array}$ \\
\hline $\begin{array}{l}\text { Phytophthora } \\
\text { spp. }\end{array}$ & Irrigation water, infected soil & $\begin{array}{l}\text { Water-saturated soils and higher soil } \mathrm{pH} \text { levels } \\
\quad(<8) \text {, variable effects of temperature and nitrogen }\end{array}$ & $\begin{array}{l}\text { (Lambert 1936; Duniway 1983b; } \\
\text { Schmitthenner and Canaday 1983) }\end{array}$ \\
\hline Fusarium spp. & $\begin{array}{l}\text { Contaminated seeds } \\
\text { (in soil or growing media, } \\
\text { and on used containers), } \\
\text { airborne spores }\end{array}$ & $\begin{array}{l}\text { Higher soil } \mathrm{pH} \text { and with increased } \mathrm{N} \text { levels, variable } \\
\text { effects of temperature often depending on the pathogen } \\
\text { of the isolates }\end{array}$ & $\begin{array}{l}\text { (Tint 1945; Huang and Kuhlman 1990; } \\
\text { James 2012a) }\end{array}$ \\
\hline $\begin{array}{l}\text { Rhizoctonia } \\
\text { spp. }\end{array}$ & $\begin{array}{l}\text { Seeds, airborne spores, } \\
\text { infected soil }\end{array}$ & $\begin{array}{l}\text { High soil temperatures and increasing dryness } \\
\text { (reduced moisture). No particular effect of } \mathrm{pH} \text {, } \\
\text { low } \mathrm{C} / \mathrm{N} \text { ratio }\end{array}$ & $\begin{array}{l}\text { (Jackson 1940; Roth and Riker 1943; } \\
\text { Papavizas and Davey 1961; Starkey } \\
\text { and Enebak 2012) }\end{array}$ \\
\hline
\end{tabular}

been previously described (Hong and Moorman 2005; Stewart-Wade 2011; Zappia et al. 2014).

\subsection{Determination of potential interactions within and/or between damping-off pathogens and other living organisms}

Plant disease occurrence and development are determined by numerous interactions between host, pathogen, and prevailing environmental conditions, especially biocenosis, under the influence of cropping practices. This is especially the case of soilborne pathogens for which there are many possibilities for potential interactions with other microorganisms/agents occupying the same ecological niche. A number of recent studies reported significant interactions within and/or between several damping-off pathogens and other pathogenic organisms (Table 7). Such studies have emphasized that coinoculation of two or more pathogens consistently cause more detrimental effects on root development than either pathogen alone. These findings will guide future research on damping-off diseases, including studies of the genetic diversity within species, epidemiological and ecological features of the disease, and hostpathogen interactions, and ultimately help to develop durable and sustainable damping-off management practices.

Although our understanding about individual genetic lines of microbes causing damping-off has increased over the years, there is a severe knowledge gap about how synergistic interactions between two or more genetic lines belonging to the same or different fungal genera/pathogenic agents can lead to the occurrence and spread of damping-off diseases. Therefore, a focus to understanding such interactions would be another direction for future research, which is pivotal for the development of effective disease management strategies (Lamichhane and Venturi 2015).

\subsection{A better knowledge of the role of abiotic factors that predispose seeds and seedlings to damping-off diseases}

Overall, while there is good knowledge in the literature concerning the role of individual abiotic factors on dampingoff (especially soil moisture and temperature), little is known about how interactions between abiotic and biotic factors lead to the occurrence of such diseases. Few works performed on abiotic stresses have highlighted that a number of abiotic factors predispose seed or seedlings to damping-off pathogens and increase the severity of infection. This is mainly due to certain soil and climate factors, which restrict normal seed and root growth and development (Burke et al. 1972a, b). In particular, wet (e.g., due to poor drainage or overwatering) and cool soils, cool to moderate air temperatures, are particularly favorable for the development of key damping-off pathogens (Table 3). Key predisposing factors, which trigger the development of Fusarium, Rhizoctonia, Pythium, and Phytophthora species are reported in Table 6.

Soil characteristics including soil aggregate size and texture markedly affect seedling emergence. Aggregate size influences the way the soil water content changes with time and the seed-soil contact, the path of the seedling to the soil surface, and the rate of soil surface degradation by rainfall. Greater soil aggregates size also represents mechanical obstacles for seedlings (Dürr and Aubertot 2000). Soil compaction is another factor causing stress in plants, especially where mechanized crop production is practiced, resulting in reduced root development (Allmaras et al. 1988; Harveson et al. 2005). Excessive soil compaction decreases porosity, degrades soil 
Table 7 Selection of synergistic interactions within and/or between damping-off pathogens and other pathogenic organisms reported since 2000

\begin{tabular}{|c|c|c|}
\hline Host & Interactions between & References \\
\hline Cassava & Fusarium spp. & (Bandyopadhyay et al. 2006) \\
\hline Cereals & Fusarium spp. & (Del Ponte et al. 2014) \\
\hline Chile pepper & Rhizoctonia solani and Meloidogyne incognita & (Al-Hammouri et al. 2013) \\
\hline Clover & Root-infecting fungi and parasitic nematodes & (You et al. 2000) \\
\hline Coffee & Meloidogyne arabicida and Fusarium oxysporum & (Bertrand et al. 2000) \\
\hline Ginger & Pythium spp. & (Le et al. 2014) \\
\hline Green beans & Meloidogyne incognita and Rhizoctonia solani & (Al-Hazmi and Al-Nadary 2015) \\
\hline Lentil & $\begin{array}{l}\text { Fusarium oxysporum } f \text {.sp. lentis and Meloidogyne } \\
\text { javanica }\end{array}$ & (De et al. 2001) \\
\hline Maize & Pythium and Fusarium spp. & $\begin{array}{l}\text { (Harvey et al. 2008; Lamprecht et al. } \\
\text { 2011) }\end{array}$ \\
\hline $\begin{array}{l}\text { Parsnip and } \\
\text { parsley }\end{array}$ & Pythium spp. & (Petkowski et al. 2013) \\
\hline Soybean & Fusarium spp. & (Barros et al. 2014) \\
\hline Soybean & $\begin{array}{l}\text { Rhizoctonia spp. and other microbes and nematode } \\
\text { communities }\end{array}$ & (Liu et al. 2016) \\
\hline Soybean & Phytophthora sojae and Heterodera glycines & (Kaitany et al. 2000) \\
\hline Potato & Rhizoctonia solani and plant parasitic nematodes & $\begin{array}{l}\text { (Back et al. 2000; Karlsson 2006; Björsell } \\
\text { 2015) }\end{array}$ \\
\hline Tomato & Rhizoctonia solani and Meloidogyne incognita & $\begin{array}{l}\text { (Kumar and Haseeb 2009; Vidya Sagar } \\
\text { et al. 2012) }\end{array}$ \\
\hline
\end{tabular}

structure, and can impede water movement and root growth thereby predisposing seeds or seedlings to biotic stresses.

Higher salinity levels have been reported to trigger damping-off diseases. A recent study found an evidence about a synergistic interaction between salinity stress of seed or seedlings and salinity-tolerant Pythium species (Al-Sadi et al. 2010). Other studies showed an enhanced level of disease development on a number of crops due to higher salinity levels (Rasmussen and Stanghellini 1988; Sanogo 2004; Triky-Dotan et al. 2005). Likewise, heat developed just above the ground line can lead to seedling stresses or damages (Helgerson 1989).

\subsection{Development of disease-suppressive seedbed soils with or without conservation agriculture}

Suppressive soils provide an environment in which plant disease development is reduced, even in the presence of a pathogen and a susceptible host (Hadar and Papadopoulou 2012). Although several studies have reported the potentiality of disease-suppressive soils, their practical application is still limited. The reason behind is the lack of reliable prediction and quality control tools for assessing the level and specificity of the suppression effect. This is especially true taking into account the very complex soil environment with a high level of dynamic complexity and interactions occurring among microbes, plants, and the environment (Lemanceau et al. 2015). More specifically to damping-off, the development of a specific means that suppresses the development of a given damping-off pathogen may not provide a satisfactory suppression of another pathogen thereby questioning the durability of this approach. Indeed, a suppressive soil to one pathogen may not necessarily be suppressive to another due to specificity in the soil-plant-microbe interactions (Whipps 2001). Therefore, the creation of disease-suppressive seedbed environments that discourage the development of most damping-off pathogens is a challenging task for research. A previous study (Bonanomi et al. 2007) reported variable suppressive effects of organic amendments although in most cases such materials provided an effective disease suppressiveness. Another concern is that the suppressive effects of certain amendments, such as composts, are relatively lower and more variable when they are applied in the field compared to container media (Noble and Coventry 2005).

The difficulties in evaluating the level and specificity of the suppression effect can, however, be addressed, at least to some extent, using modern methods of analyzing microbial community structures, including metagenomics. The latter allow identification of both culturable and non-culturable microorganisms and thus provide important insights to help define the key organisms or groups of organisms that allow to exercise natural suppression of damping-off pathogens. However, to guide research in microbial ecology in complex environments, such as soil, there is a lack of ecological theory, which hinders hypothesis-driven research and interpretation of metadata, especially while dealing with compost and compost-amended environments (Prosser et al. 2007; Hadar and Papadopoulou 2012). In particular, our knowledge is still poor concerning why there are numerous cases of compost-mediated disease suppression but no or rare cases of suppressive soils at local levels (i.e., under field conditions). To respond to this question, a recent study identified common traits that have been regarded as potential indicators of suppression (Hadar and Papadopoulou 2012). A better understanding of these 
Fig. 8 Generic conceptual model that represents the impact of cropping practices and weather on biotic and abiotic stresses affecting seed germination and seedling emergence

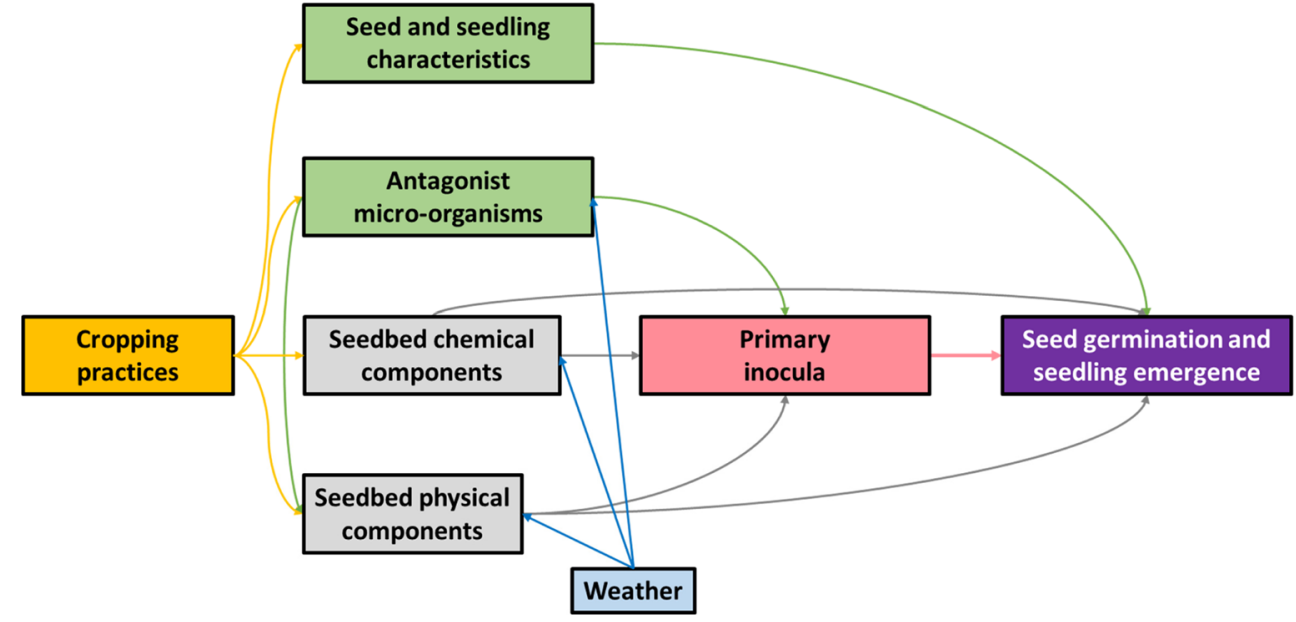

indicators may surely help develop disease-suppressive soils thereby contributing to damping-off management.

Because suppressive soil to one pathogen may not always be suppressive to another, there is a need for individual evaluation of compost products for specific pathosystems and the development of standardized compost production and storage protocols. At the same time, there needs a better focus towards a development of suppressive soils under field conditions by optimizing already existing compost-based amendments or combining every single tool and/or strategy that allows to enhance a disease-suppressive soil environment. This includes manipulation of the physiochemical and microbiological environment via best management practices and biological control using organisms such as Trichoderma spp. (Tables 2, 3, and 4).

Overall, there is a paucity of information in the literature concerning how conservation agriculture may affect dampingoff diseases although prediction can be made from traditional epidemiological knowledge. Because the major damping-off pathogens discussed in this paper have a broad host range, the retention of crop residues on soil surface maybe a nutrient (food) source for the pathogens after harvest as well the presence of cover crops may act as a potential reservoir of these pathogens (intermediate hosts; (Bockus and Shroyer 1998; Cook 2001). For example, in areas with infected crop residues, infected seeds contribute to a rather small part of the inoculum as seeds and seedlings can be infected during their development. In addition, no-till fields maintain more surface residues than conventional-till fields, at least early in the season (Lindstrom and Onstad 1984; Govaerts et al. 2007), which means more moisture (Belvins et al. 1971; Power et al. 1986), a condition that favors development of damping-off pathogens (Schmitthenner and Van Doran 1985). Further, while the presence of crop residues may act as a physical barrier and prevent pathogens from being spread through soil movement by wind, water, or agricultural equipment, such effects may not be applied to damping-off pathogens given their soil-borne nature.
The little information available in the literature shows that conservation agriculture may have variable effects on damping-off pathogens. For instance, a reduction of tillage has been reported to have both negative (Dick and Van Doran 1985; Schmitthenner and Van Doran 1985; Adandonon et al. 2004) and positive (Tachibana 1983; Rovira 1986; Cook and Haglund 1991; Paulitz et al. 2002; Govaerts et al. 2007) effects on dampingoff pathogens development. A previous study (Workneh et al. 1998) demonstrated the recovery of Phytophthora sojae in greater frequency near the soil surface in no-till fields than in conventional-till fields. This suggests that the potential development of damping-off diseases may be greater in no-till fields than in conventional-till ones. However, Schillinger et al. (2010) demonstrated that when no-till regime was included in a conservation agriculture approach (i.e., together with a more complex rotation and a permanent soil coverage), the incidence of Gaeumannomyces graminis var. tritici was decreased in comparison to continuous annual winter wheat, independently of the soil management. As for $R$. solani, no grain yield loss was observed in any kind of treatment applied although it was more pronounced in the no-till treatments. Very similar results were obtained by other authors while dealing with several cereal pathogens (Matusinsky et al. 2009; Paulitz et al. 2009).

However, it is worth to highlight that most of these studies were based on short-term experiments and we do not know how direct seeding affects damping-off disease over longer periods of time. Moreover, most of the results come from researches on partially-applied conservation agriculture systems, whereas it is well known that full benefits of conservation agriculture are delivered when its three principles are applied for several years (Farooq and Siddique 2015). Hence, more research efforts, based on long-term experiments, are needed to better elucidate the effects of conservation agriculture on these pathogens, which may differ case by case. 


\subsection{Modeling to help design integrated management strategies of damping-off diseases}

Despite several benefits they provide, simulation studies were rarely performed to understand seed germination and seedling emergence. However, a model called SIMPLE (SIMulation of Plant Emergence) was previously developed and used to predict the effects of the main physical factors within the seedbed, including soil temperature and water potential, as well as mechanical obstacles to germination and emergence (Dürr et al. 2001). A few subsequent studies attempted to evaluate the effects of sowing conditions using the same model, including sowing date, sowing depth and seedbed preparation, or of seed lot characteristics (Dorsainvil et al. 2005; Moreau-Valancogne et al. 2008; Constantin et al. 2015). This SIMPLE model was also used to analyze the extent of the effects of plant genetic diversity on seed emergence rates under a wide range of environmental conditions (Brunel-Muguet et al. 2011; Dürr et al. 2016).

Little efforts towards the modeling of damping-off diseases have been undertaken so far. Early epidemiological modeling approaches were conducted in order to mathematically describe soil-borne diseases as a function of inoculum density (Baker 1971; Grogan et al. 1980). These approaches always relied on data sets obtained by experiments where one or more rarely several factors would vary. For instance, Burdon and Chilvers (1975) analyzed and modeled the impact of clumped planting patterns on epidemics of damping-off disease (Pythium irregulare) in cress seedling as a function of number of clumps per unit area. Furthermore, similar modeling approaches permitted to model soil suppressiveness to $R$. solani (Wijetunga and Baker 1979). Often, these approaches linked observed data to simple theoretical epidemiological models that were fitted to describe disease epidemics. Gilligan (1983) proposed a typology of the early modeling approaches in the field of soil-borne epidemiology: models for primary infection (rhizosphere models; surface density models; probability models); models for secondary infections (for three types of pathogens: unspecialized pathogens such as damping-off and non-ectotrophic root rotting fungi; specialized ectotrophic pathogens; specialized systemic pathogens); models for disease progress (growth curve analysis: nonlinear models such as the ones proposed by van der Plank (1963); epidemiological models embedding host growth; multivariate methods; and computer simulations). Otten et al. (2003) proposed a simple compartmental model S-I (susceptible-infected) to model transmission rates for soil-borne epidemics as a function of primary inoculum density ( $R$. solani) and the number of contacts of plants. It was later extended to take into account soil suppressiveness (Otten et al. 2004). More recent works allowed to model the impact of crop sequence on attacks of Fusarium oxysporum f.sp. cepae (Leoni et al. 2013), or the impact of climate change on six soil-borne fungal plant pathogens using a generic model associated to data on the impact of temperature obtained in controlled chambers and a soil humidity model (Manici et al. 2014).

Because there is a lack of tools to help design integrated management strategies of damping-off diseases, frameworks derived from the conceptual model, as presented in Fig. 8, would be very useful. Such models should integrate the impact of cropping practices and weather on the physical and chemical components of seedbed along with their impact on damping-off disease primary inocula from multiple pathogens and antagonistic microorganisms. As reported in Fig. 8, interactions between cropping practices and production situations are numerous and such models should integrate mechanisms as parsimoniously as possible. For instance, the abovementioned SIMPLE model could be used as a basis to develop such models since it already integrates the major abiotic stresses (thermal, hydric, and mechanical stress).

Future research, combining experimental and modeling approaches, should focus on a better understanding of the role of abiotic stresses in damping-off diseases. In addition, diagnoses of commercial fields with various levels of damping-off symptoms could also help analyze the effects of interactions between cropping practices and production situations on the biotic and abiotic drivers of damping-off. The developed models would thus significantly improve our understanding of the critical interactions between biotic and abiotic factors that affect damping-off diseases and would help design integrated management strategies of dumping-off diseases.

\section{Conclusions and perspectives}

The great economic importance of damping-off diseases and increasing concerns in finding sustainable solutions to this problem imply that opportunities exist to develop IPM strategies. Achieving this outcome will require a greater understanding of the ecology, genetics, and pathogenicity of the microbes associated with the disease. Research should focus on critical niches of complexity, such as seed, seedbed, associated microbes, and their interfaces, for which innovative and robust experimental and modeling approaches are needed. In particular, development and validation of new simulation models or improvement of those already existing ones may result useful.

Legislative pressure, fueled by public concern over the use of conventional pesticides in agriculture, requires that alternative to conventional pesticides be developed and applied for a durable and sustainable disease management. Nevertheless, management of damping-off appears to be less straightforward than one might expect. Given that several pathogenic organisms interact and cause damping-off, it is fundamental to have prior knowledge of the interaction concerned, as even a very low population density of soil-borne pathogens can lead to severe epidemic development. Consequently, the 
prevention or containment of one pathogen may not resolve the problem of the interaction. Therefore, there is a remarkable need for a better understanding of the interactions between plants, the environment and natural resident microbial agents/communities, under the influence of cropping practices. The information reported in this paper underlines the necessity of understanding such a complex relationship, which is essential for an effective decision-making process on damping-off disease management.

Acknowledgements We are grateful to Prof. Lindsey J. du Toit, Washington State University, USA, and Dr. Martin Chilvers, Michigan State University, USA, for providing high-quality photos of damping-off disease symptoms. We also thank the participants of the Rés0Pest IPM network (DEPHY EXPE ECOPHYTO), coordinated by the INRA/CIRAD, who provided the data shown in Fig. 6, and in particular Guillaume Audebert, Alain Berthier, Caroline Colnenne, Sébastien Darras, Violaine Deytieux, André Gavaland, Philippe Le Roy, and Antoine Savoie.

\section{References}

Abbasi PA, Lazarovits G (2005) Effects of AG3 phosphonate formulations on incidence and severity of Pythium damping-off of cucumber seedlings under growth room, microplot, and field conditions. Can J Plant Pathol 27:420-429. doi:10.1080/07060660509507241

Abbasi PA, Lazarovits G (2006) Seed treatment with phosphonate (AG3) suppresses Pythium damping-off of cucumber seedlings. Plant Dis 90:459-464. doi:10.1094/PD-90-0459

Abdel-Monaim MF, Abo-Elyousr KAM (2012) Effect of preceding and intercropping crops on suppression of lentil damping-off and root rot disease in New Valley - Egypt. Crop Prot 32:41-46. doi:10.1016/j. cropro.2011.10.011

Abdelzaher HMA (2004) Occurrence of damping-off of wheat caused by Pythium diclinum tokunaga in El-Minia, Egypt and its possible control by Gliocladium roseum and Trichoderma harzianum. Arch Phytopathol Plant Prot 37:147-159. doi:10.1080 /0323540042000205893

Adandonon A, Aveling TAS, Tamo M (2004) Occurrence and distribution of cowpea damping-off and stem rot and associated fungi in Benin. J Agric Sci 142:561-566. doi:10.1017/S0021859604004629

Agrios GN (2005) Plant pathology. Academic Press, New York, N.Y

Agustí-Brisach C, Pérez-Sierra A, García-Figueres F et al (2011) First report of damping-off caused by Cylindrocarpon pauciseptatum on Pinus radiata in Spain. Plant Dis 95:874. doi:10.1094/PDIS02-11-0125

Aiello D, Castello I, Vitale A et al (2008a) First report of damping-off on African daisy caused by Rhizoctonia solani AG-4 in Italy. Plant Dis 92:1367. doi:10.1094/PDIS-92-9-1367B

Aiello D, Parlavecchio G, Vitale A et al (2008b) First report of dampingoff caused by Rhizoctonia solani AG-4 on Lagunaria patersonii in Italy. Plant Dis 92:836. doi:10.1094/PDIS-92-5-0836A

Alcala AVC, Paulitz TC, Schroeder KL et al (2016) Pythium species associated with damping-off of pea in certified organic fields in the Columbia basin of Central Washington. Plant Dis 100:916925. doi:10.1094/PDIS-07-15-0774-RE

Al-Hammouri A, Lindemann W, Sanogo S et al (2013) Interaction between Rhizoctonia solani and Meloidogyne incognita on Chile pepper in soil infested simultaneously with both plant pathogens. Can J Plant Sci 93:67-69. doi:10.4141/cjps2012-037
Al-Hazmi AS, Al-Nadary SN (2015) Interaction between Meloidogyne incognita and Rhizoctonia solani on green beans. Saudi J Biol Sci 22:570-574. doi:10.1016/j.sjbs.2015.04.008

Allain-Boulé N, Lévesque CA, Martinez C et al (2004) Identification of Pythium species associated with cavity-spot lesions on carrots in eastern Quebec. Can J Plant Pathol 26:365-370. doi:10.1080 /07060660409507154

Allmaras RR, Kraft JM, Miller DE (1988) Effects of soil compaction and incorporated crop residue on root health. Annu Rev Phytopathol 26: 219-243

Almaliky BSA, Abidin MAZ, Kader J, Wong MY (2012) First report of Marasmiellus palmivorus causing post-emergence damping off on coconut seedlings in Malaysia. Plant Dis 97:143. doi:10.1094/PDIS07-12-0627-PDN

Al-Sa'di AM, Drenth A, Deadman ML et al (2007) Molecular characterization and pathogenicity of Pythium species associated with damping-off in greenhouse cucumber (Cucumis sativus) in Oman. Plant Pathol 56:140-149. doi:10.1111/j.1365-3059.2006.01501.x

Al-Sadi AM, Al-Masoudi RS, Al-Habsi N et al (2010) Effect of salinity on pythium damping-off of cucumber and on the tolerance of Pythium aphanidermatum. Plant Pathol 59:112-120. doi:10.1111 /j.1365-3059.2009.02176.x

Aubertot J-N, Robin M-H (2013) Injury profile SIMulator, a qualitative aggregative modelling framework to predict crop injury profile as a function of cropping practices, and the abiotic and biotic environment. I. Conceptual bases. PLoS One 8(9):e73202. doi:10.1371 journal.pone. 0073202

Aubertot J-N, Dürr C, Richard G et al (2002) Are penetrometer measurements useful in predicting emergence of sugar beet (Beta vulgaris L.) seedlings through a crust? Plant Soil 241:177-186. doi:10.1023 /A:1016170329919

Axelrood PE, Neumann M, Trotter D et al (1995) Seedborne Fusarium on Douglas-fir: pathogenicity and seed stratification method to decrease Fusarium contamination. New For 9:35-51. doi:10.1007 /BF00028924

Babadoost M, Islam SZ (2003) Fungicide seed treatment effects on seedling damping-off of pumpkin caused by Phytophthora capsici. Plant Dis 87:63-68. doi:10.1094/PDIS.2003.87.1.63

Babai-Ahary A, Abrinnia M, Heravan IM (2004) Identification and pathogenicity of Pythium species causing damping-off in sugarbeet in Northwest Iran. Australas Plant Pathol 33:343-347. doi:10.1071 /AP04038

Bacharis C, Gouziotis A, Kalogeropoulou P et al (2010) Characterization of Rhizoctonia spp. isolates associated with damping-off disease in cotton and tobacco seedlings in Greece. Plant Dis 94:1314-1322. doi:10.1094/PDIS-12-09-0847

Back MA, Jenkinson P, Haydock PPJ (2000) The interaction between potato cyst nematodes and Rhizoctonia solani diseases in potatoes. Proc. Bright. Crop Prot. Conf. Pests Dis. British Crop Protection Council, Farnham, UK, pp 503-506

Bahramisharif A, Lamprecht SC, Calitz F, McLeod A (2013a) Suppression of pythium and Phytophthora damping-off of rooibos by compost and a combination of compost and nonpathogenic Pythium taxa. Plant Dis 97:1605-1610. doi:10.1094/PDIS-04-130360-RE

Bahramisharif A, Lamprecht SC, Spies CFJ et al (2013b) Pythium spp. associated with rooibos seedlings, and their pathogenicity toward rooibos, lupin, and oat. Plant Dis 98:223-232. doi:10.1094/PDIS05-13-0467-RE

Bai Q, Xie Y, Wang X et al (2011) First report of damping-off of Rhodiola sachalinensis caused by Rhizoctonia solani AG-4 HG-II in China. Plant Dis 96:142. doi:10.1094/PDIS-07-11-0559

Bailey KL, Lazarovits G (2003) Suppressing soil-borne diseases with residue management and organic amendments. Soil Tillage Res 72:169-180. doi:10.1016/S0167-1987(03)00086-2 
Baker R (1971) Analyses involving inoculum density of soil-borne plant pathogens in epidemiology. Phytopathology 61:1280-1292

Bandyopadhyay R, Mwangi M, Aigbe SO, Leslie JF (2006) Fusarium species from the cassava root rot complex in West Africa. Phytopathology 96:673-676. doi:10.1094/PHYTO-96-0673

Bardin SD, Huang HC, Liu L, Yanke LJ (2003) Control, by microbial seed treatment, of dampingoff caused by Pythium sp. on canola, safflower, dry pea, and sugar beet. Can J Plant Pathol 25:268-275. doi:10.1080/07060660309507079

Bardin SD, Huang HC, Moyer JR (2004a) Control of pythium dampingoff of sugar beet by seed treatment with crop straw powders and a biocontrol agent. Biol Control 29:453-460. doi:10.1016/j. biocontrol.2003.09.001

Bardin SD, Huang HC, Pinto J et al (2004b) Biological control of pythium damping-off of pea and sugar beet by Rhizobium leguminosarum bv. viceae. Can J Bot 82:291-296

Bargabus RL, Zidack NK, Sherwood JE, Jacobsen BJ (2002) Characterisation of systemic resistance in sugar beet elicited by a non-pathogenic, phyllosphere-colonizing Bacillus mycoides, biological control agent. Physiol Mol Plant Pathol 61:289-298. doi:10.1006/pmpp.2003.0443

Bargabus RL, Zidack NK, Sherwood JE, Jacobsen BJ (2004) Screening for the identification of potential biological control agents that induce systemic acquired resistance in sugar beet. Biol Control 30: 342-350. doi:10.1016/j.biocontrol.2003.11.005

Barros GG, Zanon MSA, Chiotta ML et al (2014) Pathogenicity of phylogenetic species in the Fusarium graminearum complex on soybean seedlings in Argentina. Eur J Plant Pathol 138:215-222. doi:10.1007/s10658-013-0332-2

Beech WS (1949) The effects of excess solutes, temperature and moisture upon damping-off. Pennsylvania Agric Exp Stn Bull 509:29

Belvins RL, Cook D, Phillips SH, Phillips RE (1971) Influence of notillage on soil moisture. Agron J 63:593-596

Benhamou N (2004) Potential of the mycoparasite, Verticillium lecanii, to protect citrus fruit against Penicillium digitatum, the causal agent of green mold: a comparison with the effect of chitosan. Phytopathology 94:693-705. doi:10.1094 /PHYTO.2004.94.7.693

Benhamou N, Chet I (1997) Cellular and molecular mechanisms involved in the interaction between Trichoderma harzianum and Pythium ultimum. Appl Environ Microbiol 63:2095-2099

Ben-Yephet Y, Nelson EB (1999) Differential suppression of damping-off caused by Pythium aphanidermatum, P. irregulare, and P. myriotylum in composts at different temperatures. Plant Dis 83: 356-360. doi:10.1094/PDIS.1999.83.4.356

Bertrand B, Nunez C, Sarah JL (2000) Disease complex in coffee involving Meloidogyne arabicida and Fusarium oxysporum. Plant Pathol 49:383-388. doi:10.1046/j.1365-3059

Bik HM, Porazinska DL, Creer S et al (2016) Sequencing our way towards understanding global eukaryotic biodiversity. Trends Ecol Evol 27:233-243. doi:10.1016/j.tree.2011.11.010

Björsell P (2015) Interactions between some plantparasitic nematodes and Rhizoctonia solani in potato fields. The Swedish University of Agricultural Sciences

Bockus WW, Shroyer JP (1998) The impact of reduced tillage on soilborne plant pathogens. Annu Rev Phytopathol 36:485-500. doi:10.1146/annurev.phyto.36.1.485

Bonanomi G, Antignani V, Pane C, Scala F (2007) Suppression of soilborne fungal diseases with organic amendments. J Plant Pathol 89: 311-324

Bourguet D, Guillemaud T (2016) The hidden and external costs of pesticide use. In: Lichtfouse E (ed) Sustain. Agric. Rev, Vol, vol 19. Springer International Publishing, Cham, pp 35-120. doi:10.1007 1978-3-319-26777-7 2

Boyce JS (1961) Forest pathology, third. McGrawHill, USA, New York
Bradley CA (2007) Effect of fungicide seed treatments on stand establishment, seedling disease, and yield of soybean in North Dakota. Plant Dis 92:120-125. doi:10.1094/PDIS-92-1-0120

Brunel-Muguet S, Aubertot J-N, Durr C (2011) Simulating the impact of genetic diversity of Medicago truncatula on germination and emergence using a crop emergence model for ideotype breeding. Ann Bot. doi:10.1093/aob/mer071

Bull CT, Shetty KG, Subbarao KV (2002) Interactions between myxobacteria, plant pathogenic fungi, and biocontrol agents. Plant Dis 86:889-896. doi:10.1094/PDIS.2002.86.8.889

Bulletin de Santé Vegetal (BSV) (2016) Résultats de l'enquête dégâts de mouche (géomyze) sur maïs en Bretagne. Technical report, p. 9 (In French)

Burdon JJ, Chilvers GA (1975) Epidemiology of damping-off disease (Pythium irregulare) in relation to density of Lepidium sativum seedlings. Ann Appl Biol 81:135-143. doi:10.1111/j.17447348.1975.tb00530.x

Burke DW, Holmes LD, Barker AW (1972a) Distribution of Fusarium solani $\mathrm{f}$. Sp. phaseoli and bean roots in relation to tillage and soil compaction. Phytopathology 62:550-554

Burke DW, Miller DE, Holmes LD, Barker AW (1972b) Counteracting bean root rot by loosening the soil. Phytopathology 62:306-309

Burns JR, Benson DM (2000) Biocontrol of damping-off of Catharanthus roseus caused by Pythium ultimum with Trichoderma virens and Binucleate Rhizoctonia fungi. Plant Dis 84:644-648. doi:10.1094/PDIS.2000.84.6.644

Carisse O, Bernier J, Benhamou N (2003) Selection of biological agents from composts for control of damping-off of cucumber caused by Pythium ultimum. Can J Plant Pathol 25:258-267. doi:10.1080 /07060660309507078

Carling DE, Summer DR (1992) Rhizoctonia. In: Singleton L, Mihail JD, Rush CM (eds) Methods res. Soilborne Phytopathogenic fungi. American Phytopathological Society, St Paul, MN, the USA, pp $157-165$

Carling DE, Baird RE, Gitaitis RD et al (2002) Characterization of AG13, a newly reported anastomosis Group of Rhizoctonia solani. Phytopathology 92:893-899. doi:10.1094/PHYTO.2002.92.8.893

Chandanie WA, Kubota M, Hyakumachi M (2009) Interactions between the arbuscular mycorrhizal fungus Glomus mosseae and plant growth-promoting fungi and their significance for enhancing plant growth and suppressing damping-off of cucumber (Cucumis sativus L.) Appl Soil Ecol 41:336-341. doi:10.1016/j.apsoil.2008.12.006

Chen CQ, Belanger RR, Benhamou N, Paulitz TC (2000) Defense enzymes induced in cucumber roots by treatment with plant growthpromoting rhizobacteria (PGPR) and Pythium aphanidermatum. Physiol Mol Plant Pathol 56:13-23. doi:10.1006/pmpp.1999.0243

Coffua LS, Veterano ST, Clipman SJ et al (2016) Characterization of Pythium spp. associated with asymptomatic soybean in southeastern Pennsylvania. Plant Dis. doi:10.1094/PDIS-11-15-1355-RE

Coles RB, Wicks TJ (2003) The incidence of Alternaria radicina on carrot seeds, seedlings and roots in South Australia. Australas Plant Pathol 32:99-104. doi:10.1071/AP02069

Constantin J, Dürr C, Tribouillois H, Justes E (2015) Catch crop emergence success depends on weather and soil seedbed conditions in interaction with sowing date: a simulation study using the SIMPLE emergence model. F Crop Res 176:22-33. doi:10.1016/j. fcr.2015.02.017

Cook RJ (2001) Management of wheat and barley root diseases in modern farming systems. Australas Plant Pathol 30:119-126. doi:10.1071/AP01010

Cook JR, Haglund WA (1991) Wheat yield depression associated with conservation tillage caused by root rot pathogens not phytotoxins from the straw. Soil Biol Biochem 23:1125-1132

Cook RJ, Ownley BH, Zhang H, Vakoch D (2000) Influence of pairedrow spacing and fertilizer placement on yield and root diseases of direct-seeded wheat. Crop Sci 40:1079-1087 
Cram MM (2003) Damping-Off. Tree Plant Notes 50:1-5

Crous PW (2002) Damping-off. In: Crous PW (ed) Taxonomy and pathology of Cylindrocladium (Calonectria) and allied genera. The American Phytopathological Society, St. Paul, MN, pp 15-17

Davey CB (1996) Nursery soil management-organic amendments. In: Landis TD, South DB (eds) Natl. Proceedings, For. Conserv. Nurs. Assoc. Portland (OR), p 6-18

de los Santos-Villalobos S, Guzmán-Ortiz DA, Gómez-Lim MA et al (2013) Potential use of Trichoderma asperellum (Samuels, Liechfeldt et Nirenberg) $\{\mathrm{T} 8 \mathrm{a}\}$ as a biological control agent against anthracnose in mango (Mangifera indica L.) Biol Control 64:37-44. doi:10.1016/j.biocontrol.2012.10.006

De RK, Ali SS, Dwivedi RP (2001) Effect of interaction between Fusarium oxysporum f.sp. lentis and Meloidogyne javanica on lentil. Indian J Pulses Res 14:71-73

Deadman M, Al Hasani H, Al Sadi A (2006) Solarization and biofumigation reduce Pythium aphanidermatum induced dampingoff and enhance vegetative growth of greenhouse cucumber in Oman. J Plant Pathol 88:335-337

Del Ponte EM, Spolti P, Ward TJ et al (2014) Regional and field-specific factors affect the composition of Fusarium head blight pathogens in subtropical no-till wheat agroecosystem of Brazil. Phytopathology. doi:10.1094/PHYTO-04-14-0102-R

Deytieux V, Bernicot MH, Cellier V, et al. (2014) An experimental network to study pesticide free cropping systems in arable crops. In: Szilvássy Z (ed) 13th Congr. Eur. Soc. Agron. Debrecen, Hungary, p 339-340

Diab HG, Hu S, Benson DM (2003) Suppression of Rhizoctonia solani on impatiens by enhanced microbial activity in composted swine waste-amended potting mixes. Phytopathology 93:1115-1123. doi:10.1094/PHYTO.2003.93.9.1115

Dias MC (2012) Phytotoxicity: an overview of the physiological responses of plants exposed to fungicides. J Bot. doi:10.1155/2012 $/ 135479$

Dick WA, Van Doran DM (1985) Continuous tillage and rotation combinations effects on corn, soybean, and oat yields. Agron J 77:459465

Dole JM, Wilkins HF (2004) Floriculture principles and species. Prentice Hall, Englewood. Cliffs, New Jersey

Dorrance AE, Robertson AE, Cianzo S et al (2009) Integrated management strategies for Phytophthora sojae combining host resistance and seed treatments. Plant Dis 93:875-882. doi:10.1094/PDIS-939-0875

Dorsainvil F, Durr C, Justes E, Carrera A (2005) Characterisation and modelling of white mustard (Sinapis alba L.) emergence under several sowing conditions. Eur J Agron 23:146-158. doi:10.1016/j. eja.2004.11.002

du Toit LJ (2004) Management of diseases in seed crops, in Encyclopedia of Plant and Crop Science. In: Dekker GRM (ed) Encycl. Plant Crop Sci. New York, p 675-677

Dumroese RK, James RL (2005) Root diseases in bareroot and container nurseries of the Pacific Northwest: epidemiology, management, and effects on outplanting performance. New For 30:185-202. doi:10.1007/s11056-005-4422-7

Duniway JM (1983a) Role of physical factors in the develop-ment of Phytophthora diseases. In: Erwin DC, Bartnicki-Garcia S, Tsao PH (eds) Phytophthora its Biol. Taxon. Ecol. Pathol. American Phytopathological Society, Saint Paul, MN, pp 175-187

Duniway JM (1983b) Role of physical factors in the develop-ment of Phytophthora diseases. In: Erwin DC, Bartnicki-Garcia S, Tsao PH (eds) Phytophthora its Biol. Taxon. Ecol. Pathol. American Phytopathological Society, St. Paul, Minn, USA, pp 175-187

Dürr C, Aubertot J-N (2000) Emergence of seedlings of sugar beet (Beta vulgaris L.) as affected by the size, roughness and position of aggregates in the seedbed. Plant Soil 219:211-220. doi:10.1023 /A:1004723901989
Dürr C, Aubertot JN, Richard G et al (2001) SIMPLE: a model for SIMulation of PLant Emergence predicting the effects of soil tillage and sowing operations. Soil Sci Soc Am J 65:414-442. doi:10.2136 /sssaj2001.652414x

Dürr C, Constantin J, Wagner M-H, Navier H, Demilly D, Göertz S, Nesi N (2016) Virtual modeling based on deep phenotyping provides complementary data to field experiments to predict plant emergence in oilseed rape genotypes. Eur J Agron 79:90-99. doi:10.1016/j. eja.2016.06.001

Ellis ML, Arias MMD, Jimenez DRC et al (2012) First report of Fusarium commune causing damping-off, seed rot, and seedling root rot on soybean (Glycine max) in the United States. Plant Dis 97:284. doi:10.1094/PDIS-07-12-0644-PDN

El-Metwally MA, Sakr MT (2010) A novel strategy for controlling damping-off and charcoal rot diseases of sunflower plants grown under calcareous-saline soil using spermine, potassium and zinc. Plant Pathol J 9:1-13

Enjalbert J, Borg J, Forst E, et al. (2016) New challenges for breeding varieties adapted to mixed cropping systems. In: Lamichhane JR, Arseniuk E, Messéan A (eds) Breed. IPM Sustain. low-input Agric. Syst. Radzików, p 30

Farooq M, Siddique MKH (2015) Conservation agriculture: concepts, brief history, and impacts on agricultural systems. In: Farooq M, Siddique MKH (eds) Conserv. Agric. Springer International Publishing, Cham, pp 3-17

Farr DF, Rossman AY (2012) Fungal nomenclature database, systematic mycology and microbiology laboratory, ARS, USDA. http://nt.arsgrin.gov/fungaldatabases/fungushost/FungusHost.cfm.

Filer THJ, Peterson GW (1975) Damping-off. In: Peterson GW, Smith RS (eds) For. Nurs. Dis. United States. USDA Forest Service. Agriculture Handbook No. 470, Washington DC, pp 6-8

Foy CD (1984) Physiological effects of hydrogen, aluminium and manganese toxicities in acid soil. In: Pearson RW, Adams F (eds) Soil acidity liming, 2nd Editio. American Society of Agronomy, Wisconsin, pp 57-97

Garibaldi A, Gilardi G, Ortu G, Gullino ML (2013) First report of damping-off caused by Pythium aphanidermatum on leaf beet (Beta vulgaris subsp. vulgaris) in Italy. Plant Dis 97:292. doi:10.1094/PDIS-08-12-0746-PDN

Garzón CD, Molineros JE, Yánez JM et al (2011) Sublethal doses of Mefenoxam enhance Pythium damping-off of geranium. Plant Dis 95:1233-1238. doi:10.1094/PDIS-09-10-0693

Georgakopoulos DG, Fiddaman P, Leifert C, Malathrakis NE (2002) Biological control of cucumber and sugar beet damping-off caused by Pythium ultimum with bacterial and fungal antagonists. J Appl Microbiol 92:1078-1086

Gerbore J, Benhamou N, Vallance J et al (2014) Biological control of plant pathogens: advantages and limitations seen through the case study of Pythium oligandrum. Environ Sci Pollut Res 21:48474860. doi:10.1007/s11356-013-1807-6

Ghimire SR, Richardson PA, Moorman GW et al (2009) An in-situ baiting bioassay for detecting Phytophthora species in irrigation runoff containment basins. Plant Pathol 58:577-583. doi:10.1111 j.1365-3059.2008.02016.x

Gilligan CA (1983) Modeling of soilborne pathogens. Annu Rev Phytopathol 21:45-64. doi:10.1146/annurev.py.21.090183.000401

Gladstone LA, Moorman GW (1989) Pythium root rot of seedling geraniums associated with various concentrations of nitrogen, phosphorous, and soidium chloride. Plant Dis 73:733-736

Govaerts B, Fuentes M, Mezzalama M et al (2007) Infiltration, soil moisture, root rot and nematode populations after 12 years of different tillage, residue and crop rotation managements. Soil Tillage Res 94: 209-219. doi:10.1016/j.still.2006.07.013

Gravel V, Martinez C, Antoun H, Tweddell RJ (2005) Antagonist microorganisms with the ability to control Pythium damping-off of tomato 
seeds in rockwool. BioControl 50:771-786. doi:10.1007/s10526005-1312-z

Grogan RG, Sall MA, Punja ZK (1980) Concepts for modelling root infection by soilborne fungi. Phytopathology 70:361-363

Gwinn KD, Ownley BH, Greene SE et al (2010) Role of essential oils in control of Rhizoctonia damping-off in tomato with bioactive monarda herbage. Phytopathology 100:493-501. doi:10.1094/PHYTO100-5-0493

Hadar Y, Papadopoulou KK (2012) Suppressive composts: microbial ecology links between abiotic environments and healthy plants. Annu Rev Phytopathol 50:133-153. doi:10.1146/annurev-phyto081211-172914

Hammond-Kosack K, Jones JDG (2000) Responses to plant pathogens biochemistry and molecular biology of plants. Rockville

Hansen EM, Myrold DD, Hamm PB (1990) Effects of soil fumigation and cover crops on potential pathogens, microbial activity, nitrogen availability, and seedling quality in conifer nurseries. Phytopathology 80:698-704

Harman GE (2000) Myths and dogmas of biocontrol — changes in perceptions derived from research on Trichoderma harzianum T-22. Plant Dis 84:377-393

Hartley C (1918) Stem lesions caused by excessive heat. J Agric Res 14: 595-604

Hartley C (1921) Damping-off in forest nurseries. USDA Bureau of Plant Industry, Washington (DC) Bulletin 99

Hartley C, Pierce RG (1917) The control of damping-off of coniferous seedlings. USDA Bull 453:32

Harveson RM, Smith JA, Stroup WW (2005) Improving root health and yield of dry beans in the Nebraska Panhandle with a new technique for reducing soil compaction. Plant Dis 89:279-284. doi:10.1094 /PD-89-0279

Harvey PR, Warren RA, Wakelin S (2008) The Pythium-Fusarium root disease complex - an emerging constraint to irrigated maize in southern New South Wales. Aust J Exp Agric 48:367-374

He M, Tian G, Semenov AM, van Bruggen AHC (2011) Shortterm fluctuations of sugar beet damping-off by Pythium ultimum in relation to changes in bacterial communities after organic amendments to two soils. Phytopathology 102:413420. doi:10.1094/PHYTO-07-11-0189

Helgerson OT (1989) Heat damage in tree seedlings and its prevention. New For 3:333-358. doi:10.1007/BF00030044

Henricot B, Pérez Sierra A, Jung T (2014) Phytophthora pachypleura sp. nov., a new species causing root rot of Aucuba japonica and other ornamentals in the United Kingdom. Plant Pathol 63:1095-1109. doi:10.1111/ppa.12194

Hong CX, Moorman GW (2005) Plant pathogens in irrigation water: challenges and opportunities. Crit Rev Plant Sci 24:189-208. doi:10.1080/07352680591005838

Horst RK (2013) Damping-off. Westcott's plant disease handbook. Springer Netherlands, Dordrecht, p 177

Howell CR (2007) Effect of seed quality and combination fungicideTrichoderma spp. seed treatments on pre- and postemergence damping-off in cotton. Phytopathology 97:66-71. doi:10.1094 /PHYTO-97-0066

Huang HC, Erickson RS (2007) Effect of seed treatment with Rhizobium leguminosarum on Pythium damping-off, seedling height, root nodulation, root biomass, shoot biomass, and seed yield of pea and lentil. J Phytopathol 155:31-37. doi:10.1111/j.14390434.2006.01189.x

Huang JW, Kuhlman EG (1990) Fungi associated with damping-off of slash pine seedlings in Georgia. Plant Dis 74:27-30

Huang X, Zhang N, Yong X et al (2012) Biocontrol of Rhizoctonia solani damping-off disease in cucumber with Bacillus pumilus SQR-N43. Microbiol Res 167:135-143. doi:10.1016/j.micres.2011.06.002
Hwang SF, Gossen BD, Turnbull GD et al (2000) Seeding date, temperature, and seed treatment affect Pythium seedling blight of field pea. Can J Plant Pathol 22:392-399. doi:10.1080/07060660009500458

Hwang SF, Ahmed H, Turnbull GD (2008) Effect of crop rotation on canola seedling blight and soil pathogen population dynamics. Can J Plant Pathol 30:369

Iersel MW, Bugbee B (1996) Phytotoxic effects of benzimidazole fungicides on bedding plants. J Amer Soc Hort Sci 121:1095-1102

Ishiguro Y, Asano T, Otsubo K et al (2013) Simultaneous detection by multiplex PCR of the high-temperature-growing Pythium species: P. aphanidermatum, P. helicoides and P. myriotylum. J Gen Plant Pathol 79:350-358. doi:10.1007 /s10327-013-0466-2

Islam MT, Hashidoko Y, Deora A et al (2005) Suppression of dampingoff disease in host plants by the rhizoplane bacterium Lysobacter sp. strain SB-K88 is linked to plant colonization and antibiosis against soilborne Peronosporomycetes. Appl Environ Microbiol 71:37863796. doi:10.1128/AEM.71.7.3786-3796.2005

Jabaji-Hare S, Neate SM (2005) Nonpathogenic binucleate Rhizoctonia spp. and benzothiadiazole protect cotton seedlings against Rhizoctonia damping-off and alternaria leaf spot in cotton. Phytopathology 95:1030-1036. doi:10.1094/PHYTO-95-1030

Jackson LW (1940) Effects of H-ion and Al-ion concentrations on damping-off of conifers and certain causative fungi. Phytopathology 30:563-579

James RL (1997) Effects of fertilizer on selected potential plant pathogens in bareroot forest nurseries. In: Haase DL, Rose R (eds) For. Seedl. Nutr. From Nurs. To F. Oregon State University, Corvallis, Oregon, pp 27-39

James RL (2012a) Fusarium root and stem diseases. In: Cram MM, Frank MS, Mallams KM (eds) For. Nurs. Pests. USDA Forest Service. Agriculture Handbook, Washington DC, pp 117-120

James RL (2012b) Damping-off. In: Cram MM, Frank MS, Mallams KM (eds) For. Nurs. Pests. Agric. Handb, vol 680. USDA Forest Service, Washington DC, pp 115-116

Jayaraj J, Radhakrishnan NV, Velazhahan R (2006) Development of formulations of Trichoderma harzianumstrain M1 for control of damping-off of tomato caused by Pythium aphanidermatum. Arch Phytopathol Plant Prot 39:1-8. doi:10.1080/03235400500094720

Jensen B, Knudsen IMB, Madsen M, Jensen DF (2004) Biopriming of infected carrot seed with an antagonist, Clonostachys rosea, selected for control of seedborne Alternaria spp. Phytopathology 94:551560. doi:10.1094/PHYTO.2004.94.6.551

Jiang J-H, Tam S-L, Toda T, Chen L-C (2015) Controlling Rhizoctonia damping-off of Chinese mustard by using endomycorrhizal Rhizoctonia spp. isolated from orchid mycorrhizae. Plant Dis 100: 85-91. doi:10.1094/PDIS-06-14-0597-RE

Jung WJ, An KN, Jin YL et al (2003) Biological control of damping-off caused by Rhizoctonia solani using chitinase-producing Paenibacillus illinoisensis KJA-424. Soil Biol Biochem 35:12611264. doi:10.1016/S0038-0717(03)00187-1

Kageyama K, Nelson EB (2003) Differential inactiviation of seed exudates stimulation of Pythium ultimum sporangium germination by Enterobacter cloacae influences biological control efficacy on different plant species. Appl Environ Microbiol 69:1114-1120. doi:10.1128/AEM.69.2.1114-1120.2003

Kaitany R, Melakeberhan H, Bird GW, Safir G (2000) Association of Phytophthora sojae with Heterodera glycines and nutrient stressed soybeans. Nematropica 30:193-199

Kandel YR, Wise KA, Bradley CA et al (2016) Fungicide and cultivar effects on sudden death syndrome and yield of soybean. Plant Dis 100:1339-1350. doi:10.1094/PDIS-11-15-1263-RE

Karlsson A (2006) Possible interactions between Rhizoctonia solani and plant parasitic nematodes (PPN) in Swedish potato fields. The Swedish University of Agricultural Sciences 
Kassaby FY (1985) Solar-heating soil for control of damping-off diseases. Soil Biol Biochem 17:429-434. doi:10.1016/0038-0717(85 )90004-5

Kemerait RC, Vidhyasekaran P (2006) Agricultural systems. Concise Encycl plant Pathol:120-122

Khan RA (1977) Effect of high-temperature stress on the growth and seed characteristics of barley and cotton. In: Aksel R, von Borstel RC (eds) Muhammed a. Genet. Divers. Plants. Springer US, Boston, MA, pp 319-324

Kida K, Tojo M, Yano K, Kotani S (2007) First report of Pythium ultimum var. ultimum causing damping-off on okra in Japan. Plant Pathol 56: 1042. doi:10.1111/j.1365-3059.2007.01634.x

Kilic-Ekici O, Yuen GY (2003) Induced resistance as a mechanism of biological control by Lysobacter enzymogenes strain C3. Phytopathology 93:1103-1110. doi:10.1094/PHYTO.2003.93.9.1103

Kiss L (2003) A review of fungal antagonists of powdery mildews and their potential as biocontrol agents. Pest Manag Sci 59:475-483. doi:10.1002/ps.689

Kiyumi KSM (2009) Greenhouse cucumber production systems in Oman: a study on the effect of cultivation practices on crop diseases and crop yields. University of Reading

Kloepper JW, Ryu C-M, Zhang S (2004) Induced systemic resistance and promotion of plant growth by Bacillus spp. Phytopathology 94: 1259-1266. doi:10.1094/PHYTO.2004.94.11.1259

Koumoutsi A, Chen XH, Henne A et al (2004) Structural and functional characterization of gene clusters directing nonribosomal synthesis of bioactive lipopeptides in Bacillus amyloliquefaciens strain FZB42. J Bacteriol 186:1084-1096. doi:10.1128/JB.186.4.1084-1096.2004

Kraft JM, Haware MP, Halila H et al (2000) Soilborne diseases and their control. In: Knight R (ed) Link. Res. Mark. Oppor. Pulses 21st Century. Kluwer Academic Publishers, Dordrecht, pp 457-466

Kumar V, Haseeb A (2009) Interactive effect of Meloidogyne incognita and Rhizoctonia solani on the growth and yield of tomato. Indian J Nematol 39:387-388

Lambert EB (1936) A seedling wilt of black locust caused by Phytophthora parasitica. J Agric Res 467-476

Lamichhane JR, Venturi V (2015) Synergisms between microbial pathogens in plant disease complexes: a growing trend. Front Plant Sci 6: doi:10.3389/fpls.2015.00385.

Lamichhane JR, Dachbrodt-Saaydeh S, Kudsk P, Messéan A (2016) Toward a reduced reliance on conventional pesticides in European agriculture. Plant Dis 100:10-24. doi:10.1094/PDIS-05-15-0574FE

Lamprecht SC, Tewoldemedhin YT, Botha WJ, Calitz FJ (2011) Species complex associated with maize crowns and roots in the KwaZuluNatal province of South Africa. Plant Dis 95:1153-1158. doi:10.1094/PDIS-02-11-0083

Landis TD (2013) Forest nursery pests: damping-off. For Nurs Notes 2: 25-32

Lazreg F, Belabid L, Sanchez J et al (2013a) First report of Fusarium equiseti causing damping-off disease on Aleppo pine in Algeria. Plant Dis 98:1268. doi:10.1094/PDIS-02-13-0194-PDN

Lazreg F, Belabid L, Sanchez J et al (2013b) First report of Globisporangium ultimum causing Pythium damping-off on Aleppo pine in Algeria, Africa, and the Mediterranean region. Plant Dis 97:1111. doi:10.1094/PDIS-07-12-0625-PDN

Lazreg F, Belabid L, Sanchez J et al (2013c) First report of Fusarium chlamydosporum causing damping-off disease on Aleppo pine in Algeria. Plant Dis 97:1506. doi:10.1094/PDIS-02-13-0208-PDN

Lazreg F, Belabid L, Sanchez J et al (2013d) First report of Fusarium redolens as a causal agent of Aleppo pine damping-off in Algeria. Plant Dis 97:997. doi:10.1094/PDIS-12-12-1169-PDN

Lazreg F, Belabid L, Sanchez J et al (2013e) First report of Fusarium acuminatum causing damping-off disease on Aleppo pine in Algeria. Plant Dis 97:557. doi:10.1094/PDIS-06-12-0608-PDN
Le DP, Smith M, Hudler GW, Aitken E (2014) Pythium soft rot of ginger: detection and identification of the causal pathogens, and their control. Crop Prot 65:153-167. doi:10.1016/j.cropro.2014.07.021

Leach LD (1947) Growth rates of host and pathogen as factors determining the severity of preemergence damping-off. J Agric Res 75:161179

Leclere V, Bechet M, Adam A et al (2005) Mycosubtilin overproduction by Bacillus subtilis BBG100 enhances the organism's antagonistic and biocontrol activities. Appl Environ Microbiol 71:4577-4584. doi:10.1128/AEM.71.8.4577-4584.2005

Lee TO, Khan Z, Kim SG, Kim YH (2008) Amendment with peony root bark improves the biocontrol efficacy of Trichoderma harzianum against Rhizoctonia solani. J Microbiol Biotechnol 18:1537-1543

Leisso RS, Miller PR, Burrows ME (2009) The influence of biological and fungicidal seed treatments on chickpea (Cicer arietinum) damping off. Can J Plant Pathol 31:38-46. doi:10.1080 /07060660909507570

Lemanceau P, Maron P-A, Mazurier S et al (2015) Understanding and managing soil biodiversity: a major challenge in agroecology. Agron Sustain Dev 35:67-81. doi:10.1007/s13593-014-0247-0

Leoni C, de Vries M, ter Braak CJF et al (2013) Fusarium oxysporum f.sp. cepae dynamics: in-plant multiplication and crop sequence simulations. Eur J Plant Pathol 137:545-561. doi:10.1007/s10658013-0268-6

Lewis JA, Lumsden RD (2001) Biocontrol of damping-off of greenhouse-grown crops caused by Rhizoctonia solani with a formulation of Trichoderma spp. Crop Prot 20:49-56. doi:10.1016 /S0261-2194(00)00052-1

Li B, Ravnskov S, Xie G, Larsen J (2011) Differential effects of organic compounds on cucumber damping-off and biocontrol of anatagonistic bacteria. J Plant Pathol 93:43-50. doi:10.4454/jpp. v93i1.272

Li YP, You MP, Colmer TD, Barbetti MJ (2014) Effect of timing and duration of soil saturation on soilborne Pythium diseases of common bean (Phaseolus vulgaris). Plant Dis 99:112-118. doi:10.1094 /PDIS-09-13-0964-RE

Liao X, Fu Y, Zhang S, Duan YP (2011) First report of damping-off on Basella rubra caused by Rhizoctonia solani anastomosis group 4 in Florida. Plant Dis 96:288. doi:10.1094/PDIS-08-11-0639

Lievens B, Brouwer M, Vanachter ACRC et al (2006) Real-time $\{$ PCR $\}$ for detection and quantification of fungal and oomycete tomato pathogens in plant and soil samples. Plant Sci 171:155-165. doi:10.1016/j.plantsci.2006.03.009

Lindstrom MA, Onstad CA (1984) Influence of tillage systems on soil physical parameters and infiltration after planting. J Soil Water Conserv 39:149-152

Liu P, Luo L, Long C (2013) Characterization of competition for nutrients in the biocontrol of Penicillium italicum by Kloeckera apiculata. Biol Control 67:157-162. doi:10.1016/j.biocontrol.2013.07.011

Liu B, Shen W, Wei H et al (2016) Rhizoctonia communities in soybean fields and their relation with other microbes and nematode communities. Eur J Plant Pathol 144:671-686. doi:10.1007/s10658-0150805-6

Mancini V, Romanazzi G (2014) Seed treatments to control seedborne fungal pathogens of vegetable crops. Pest Manag Sci 70:860-868. doi:10.1002/ps.3693

Manici LM, Bregaglio S, Fumagalli D, Donatelli M (2014) Modelling soil borne fungal pathogens of arable crops under climate change. Int J Biometeorol 58:2071-2083. doi:10.1007/s00484-014-0808-6

Mao W, Lewis JA, Hebbar PK, Lumsden RD (1997) Seed treatment with a fungal or a bacterial antagonist for reducing corn damping-off caused by species of Pythium and Fusarium. Plant Dis 81:450 454. doi:10.1094/PDIS.1997.81.5.450

Mao W, Lumsden RD, Lewis JA, Hebbar PK (1998) Seed treatment using pre-infiltration and biocontrol agents to reduce damping-off 
of corn caused by species of Pythium and Fusarium. Plant Dis 82: 294-299. doi:10.1094/PDIS.1998.82.3.294

Maraghni M, Gorai M, Neffati M (2010) Seed germination at different temperatures and water stress levels, and seedling emergence from different depths of Ziziphus lotus. South African J Bot 76:453-459. doi:10.1016/j.sajb.2010.02.092

Marcum DB, Davis RM (2006) First report of damping-off of wild rice in California caused by Pythium torulosum. Plant Dis 90:523. doi:10.1094/PD-90-0523B

Martin FN, Abad ZG, Balci Y, Ivors K (2012a) Identification and detection of Phytophthora: reviewing our progress, identifying our needs. Plant Dis 96:1080-1103. doi:10.1094/PDIS-12-11-1036-FE

Mastouri F, Björkman T, Harman GE (2010) Seed treatment with Trichoderma harzianum alleviates biotic, abiotic, and physiological stresses in germinating seeds and seedlings. Phytopathology 100: 1213-1221. doi:10.1094/PHYTO-03-10-0091

Matny ON (2012) First report of damping-off of okra caused by Phytophthora nicotianae in Iraq. Plant Dis 97:558. doi:10.1094 /PDIS-08-12-0735-PDN

Matusinsky P, Mikolasova R, Klem K, Spitzer T (2009) Eyespot infection risks on wheat with respect to climatic conditions and soil management. J Plant Pathol 91:93-101

Mavragani DC, Abdellatif L, McConkey B et al (2007) First report of damping-off of durum wheat caused by Arthrinium sacchari in the semi-arid Saskatchewan fields. Plant Dis 91:469. doi:10.1094 /PDIS-91-4-0469A

McNew GL (1960) The nature, origin, and evolution of parasitism. In: Horsfall JG, Dimond AE (eds) Plant Pathol. An Adv. Treatise. Academic Press, New York, pp 19-69

Mcquilken MP, Gemmell J, Lahdenperä ML (2001) Gliocladium catenulatum as a potential biological control agent of damping-off in bedding plants. J Phytopathol 149:171-178. doi:10.1046/j.14390434.2001.00602.x

Menzies JD (1963) Survival of microbial plant pathogens in soil. Bot Rev 29:79-122

Messéan A, Lamichhane JR, Menard J-M (2016) Role of crop diversification to boost IPM and implications for breeding. In: Lamichhane JR, Arseniuk E, Messéan A (eds) Breed. IPM Sustain. low-input Agric. Syst, Radzików, p 6

Meziane H, Van Der Sluis I, Van Loon LC et al (2005) Determinants of Pseudomonas putida WCS358 involved in inducing systemic resistance in plants. Mol Plant Pathol 6:177-185. doi:10.1111/j.13643703.2005.00276.x

Milgroom MG, Cortesi P (2004) Biological control of chestnut blight with hypovirulence: a critical analysis. Annu Rev Phytopathol 42: 311-338. doi:10.1146/annurev.phyto.42.040803.140325

Misawa T, Kubota M, Sasaki J, Kuninaga S (2015) First report of broccoli foot rot caused by Rhizoctonia solani AG-2-2 IV and pathogenicity comparison of the pathogen with related pathogens. J Gen Plant Pathol 81:15-23. doi:10.1007/s10327-014-0551-1

Montecchio L (2005) Damping-off of beech seedlings caused by Fusarium avenaceum in Italy. Plant Dis 89:1014. doi:10.1094/PD89-1014A

Moorman GW, Kim SH (2004) Species of Pythium from greenhouses in Pennsylvania exhibit resistance to Propamocarb and Mefenoxam. Plant Dis 88:630-632. doi:10.1094/PDIS.2004.88.6.630

Moorman GW, Kang S, Geiser DM, Kim SH (2002) Identification and characterization of Pythium species associated with greenhouse floral crops in Pennsylvania. Plant Dis 86:1227-1231. doi:10.1094 /PDIS.2002.86.11.1227

Moreau-Valancogne P, Coste F, Crozat Y, Dürr C (2008) Assessing emergence of bean (Phaseolus vulgaris L.) seed lots in France: field observations and simulations. Eur J Agron 28:309-320. doi:10.1016/j.eja.2007.09.003

Mouttet R, Escobar-Gutiérrez A, Esquibet M et al (2014) Banning of methyl bromide for seed treatment: could Ditylenchus dipsaci again become a major threat to alfalfa production in Europe? Pest Manag Sci 70:1017-1022. doi:10.1002/ps.3745

Negm FB, Smith OE (1978) Effects of ethylene and carbon dioxide on the germination of osmotically inhibited lettuce seed. Plant Physiol 62: 473-376

Neher DA, Augspurger CK, Wilkinson HT (1987) Influence of age structure of plant populations on damping-off epidemics. Oecologia 74: 419-424. doi:10.1007/BF00378939

Nelson EB (1988) Biological control of Pythium seed rot and preemergence damping-off with Enterobacter cloacae and Erwinia herbicola applied as seed treatments. Plant Dis 72: $140-142$

Njoroge SMC, Riley MB, Keinath AP (2008) Effect of incorporation of Brassica spp. residues on population densities of soilborne microorganisms and on damping-off and Fusarium wilt of watermelon. Plant Dis 92:287-294. doi:10.1094/PDIS-92-2-0287

Noble R, Coventry E (2005) Suppression of soil-borne plant diseases with composts: a review. Biocontrol Sci Tech 15:3-20. doi:10.1080/09583150400015904

Ongena M, Duby F, Rossignol F et al (2004) Stimulation of the lipoxygenase pathway is associated with systemic resistance induced in bean by a nonpathogenic Pseudomonas strain. Mol PlantMicrobe Interact 17:1009-1018. doi:10.1094 /MPMI.2004.17.9.1009

Onstad DW (2013). Insect resistance management: biology, economics, and prediction. Academic Press, p 560

Otten W, Filipe JAN, Bailey DJ, Gilligan CA (2003) Quantification and analysis of transmission rates for soilborne epidemics. Ecology 84: 3232-3239. doi:10.1890/02-0564

Otten W, Filipe JAN, Gilligan CA (2004) An empirical method to estimate the effect of soil on the rate for transmission of damping-off disease. New Phytol 162:231-238. doi:10.1111/j.14698137.2004.01011.x

Ou SQ, Ji C, Sun FL et al (2015) Rhizoctonia solani AG-4 HG-I causing seedling damping-off of Schisandra chinensis in Jilin province, China. Plant Dis 100:1017. doi:10.1094/PDIS-05-15-0557-PDN

Pal KK, McSpadden B (2006) Biological control of plant pathogens. Plant Health Instr. doi:10.1094/PHI-A-2006-1117-02

Palmero D, Gálvez L, Gil-Serna J, Benito S (2012) Rhizoctonia solani as causal agent of damping off of Swiss chard in Spain. Spanish J Agric Res 10:1117-1120

Palumbo JD, Yuen GY, Jochum CC et al (2005) Mutagenesis of $\beta-1,3-$ Glucanase genes in Lysobacter enzymogenes strain $\mathrm{C} 3$ results in reduced biological control activity toward Bipolaris leaf spot of tall fescue and Pythium damping-off of sugar beet. Phytopathology 95: 701-707. doi:10.1094/PHYTO-95-0701

Pane C, Spaccini R, Piccolo A et al (2011) Compost amendments enhance peat suppressiveness to Pythium ultimum, Rhizoctonia solani and Sclerotinia minor. Biol Control 56:115-124. doi:10.1016/j. biocontrol.2010.10.002

Papavizas CG, Davey CB (1961) Saprophytic behavior of Rhizoctonia in soil. Phytopathology 51:693-699

Patterson L-M, Smiley RW, Alderman SM (1998) Effect of seed treatment fungicides and starter fertilizer on root diseases and yield of spring wheat. Fungic Nematic Tests 53:425

Paulitz TC, Bélanger RR (2001) Biological control in greenhouse systems. Annu Rev Phytopathol 39:103-133. doi:10.1146/annurev. phyto.39.1.103

Paulitz TC, Smiley RW, Cook RJ (2002) Insights into the prevalence and management of soilborne cereal pathogens under direct seeding in the Pacific Northwest, U.S.A. Can J Plant Pathol 24:416-428. doi:10.1080/07060660209507029

Paulitz TC, Okubara PA, Schillinger WF (2006) First report of dampingoff of canola caused by Rhizoctonia solani AG 2-1 in Washington state. Plant Dis 90:829. doi:10.1094/PD-90-0829B 
Paulitz TC, Schroeder KL, Schillinger WF (2009) Soilborne pathogens of cereals in an irrigated cropping system: effects of tillage, residue management, and crop rotation. Plant Dis 94:61-68. doi:10.1094 /PDIS-94-1-0061

Petkowski JE, de Boer RF, Norng S et al (2013) Pythium species associated with root rot complex in winter-grown parsnip and parsley crops in south eastern Australia. Australas Plant Pathol 42:403411. doi:10.1007/s13313-013-0211-5

Pieterse CMJ, Zamioudis C, Berendsen RL et al (2014) Induced systemic resistance by beneficial microbes. Annu Rev Phytopathol 52:347375. doi:10.1146/annurev-phyto-082712-102340

Poletto T, Maciel CG, Muniz MFB et al (2015) First report of Fusarium lacertarum causing damping-off in Casuarina equisetifolia in Brazil. Plant Dis 99:1040. doi:10.1094/PDIS12-14-1272-PDN

Polizzi G, Vitale A, Aiello D et al (2007) First report of damping-off and leaf spot caused by Cylindrocladium scoparium on different accessions of bottlebrush cuttings in Italy. Plant Dis 91:769. doi:10.1094 /PDIS-91-6-0769B

Polizzi G, Aiello D, Castello I et al (2009) First report of damping-off caused by Rhizoctonia solani AG-4 on Mediterranean fan palm in Italy. Plant Dis 94:125. doi:10.1094/PDIS-94-1-0125A

Polizzi G, Aiello D, Vitale A et al (2010) First report of damping-off caused by Rhizoctonia solani AG-4 on pink ipê (Tabebuia impetiginosa) in Italy. Plant Dis 95:78. doi:10.1094/PDIS-10-100748

Polizzi G, Aiello D, Guarnaccia V et al (2011) First report of damping-off on strawberry tree caused by Colletotrichum acutatum and C. simmondsii in Italy. Plant Dis 95:1588. doi:10.1094/PDIS-0711-0567

Power JF, Wilhelm WW, Doran JW (1986) Crop residue effects on soil environment and dryland maize and soybean production. Soil Tillage Res 8:101-111

Prosser JI, Bohannan BJM, Curtis TP et al (2007) The role of ecological theory in microbial ecology. Nat Rev Microbiol 5:384-392. doi:10.1038/nrmicro1643

Pryor BM, Asma M (2007) First report of seedling damping-off of fennel caused by Alternaria petroselini in the Netherlands. Plant Dis 91: 1688. doi:10.1094/PDIS-91-12-1688A

Punja ZK, Yip R (2003) Biological control of damping-off and root rot caused by Pythium aphanidermatum on greenhouse cucumbers. Can J Plant Pathol 25:411-417. doi:10.1080/07060660309507098

Rajkumar M, Lee KJ, Freitas H (2008) Effects of chitin and salicylic acid on biological control activity of Pseudomonas spp. against damping off of pepper. South African J Bot 74:268-273. doi:10.1016/j. sajb.2007.11.014

Ramamoorthy V, Samiyappan T, Raguchander R (2002) Enhancing resistance of tomato and hot pepper to Pythium diseases by seed treatment with fluorescent pseudomonads. Eur J Plant Pathol 108:429 441. doi:10.1023/A:1016062702102

Rasmussen SL, Stanghellini ME (1988) Effect of salinity stress on development of pythium blight in Agrostis palustris. Phytopathology 78: 1495-1497

Reeleder RD, Miller J, Capell B, Schooley J (2007) Mefenoxam sensitivity and the impact of fumigation on Pythium species and Phytophthora cactorum in ginseng soils. Can J Plant Pathol 29: 427-436. doi:10.1080/07060660709507489

Ren XX, Zhang GZ, Dai WA (2012) First report of damping-off caused by Alternaria japonica on Chinese cabbage seedlings in China. Plant Dis 96:1378. doi:10.1094/PDIS-04-12-0328-PDN

Rhodes LH, Myers DK (1989) Effect of seed treatment with metalaxyl or pyroxyfur on damping-off of alfalfa caused by Phytophthora megasperma f.sp. medicaginis. Crop Prot 8:369-372. doi:10.1016 /0261-2194(89)90057-4

Roberts DP, Lohrke SM, Meyer SLF et al (2005) Biocontrol agents applied individually and in combination for suppression of soilborne diseases of cucumber. Crop Prot 24:141-155. doi:10.1016/j. cropro.2004.07.004

Roberts DP, Lakshman DK, McKenna LF et al (2016) Seed treatment with ethanol extract of Serratia marcescens is compatible with Trichoderma isolates for control of damping-off of cucumber caused by Pythium ultimum. Plant Dis 100:1278-1287. doi:10.1094/PDIS09-15-1039-RE

Romo JT, Haferkamp MR (1987) Effects of osmotic potential, potassium chloride, and sodium chloride on germination of greasewood (Sarcobatus vermiculatus). West North Am Nat 47:110-116

Roth LF, Riker AJ (1943) Influence of temperature, moisture, and soil reaction on the damping-off of red pine seedlings by Pythium and Rhizoctonia. J Agric Res 67:273-293

Rothrock CS, Winters SA, Miller PK et al (2012) Importance of fungicide seed treatment and environment on seedling diseases of cotton. Plant Dis 96:1805-1817. doi:10.1094/PDIS-01-12-0031-SR

Rovira AD (1986) Influence of crop rotation and tillage on Rhizoctonia bare patch of wheat. Phytopathology 76:669-673

Russell K (1990) Damping-off. In: Hamm PB, Campbell SJ, Hansen EM (eds) Grow. Heal. seedlings Identif. Manag. pests Northwest For. nurseries. Forest Research Laboratory, Oregon State University. Special publication, Corvallis (OR), p 2-5

Ryu C-M, Kim J, Choi O et al (2006) Improvement of biological control capacity of Paenibacillus polymyxa $\{\mathrm{E} 681\}$ by seed pelleting on sesame. Biol Control 39:282-289. doi:10.1016/j. biocontrol.2006.04.014

Sabaratnam S, Traquair JA (2002) Formulation of a streptomyces biocontrol agent for the suppression of Rhizoctonia damping-off in tomato transplants. Biol Control 23:245-253. doi:10.1006/bcon.2001.1014

Safaiefarahani B, Mostowfizadeh-Ghalamfarsa R, Hardy GESJ, Burgess TI (2015) Re-evaluation of the Phytophthora cryptogea species complex and the description of a new species, Phytophthora pseudocryptogea sp. nov. Mycol Prog 14:1-12. doi:10.1007 /s11557-015-1129-9

Samac DA, Schraber S, Barclay S (2014) A mineral seed coating for control of seedling diseases of alfalfa suitable for organic production systems. Plant Dis 99:614-620. doi:10.1094/PDIS-03-14-0240-RE

Sánchez-Borges CA, Souza-Perera RA, Zúñiga-Aguilar JJ et al (2015) First report of Phytophthora capsici causing damping-off of Capsicum chinense in the Yucatan peninsula. Plant Dis 100:1247. doi:10.1094/PDIS-09-15-1047-PDN

Sanogo S (2004) Response of chile pepper to Phytophthora capsici in relation to soil salinity. Plant Dis 88:205-209

Saroj A, Kumar A, Saeed ST, et al. (2013) First report of Tagetes erecta damping-off caused by Ceratobasidium sp. from India. Plant Dis 97: 1251. doi:10.1094/PDIS-02-13-0145-PDN

Scattolin L, Montecchio L (2007) First report of damping-off of common oak plantlets caused by Cylindrocladiella parva in Italy. Plant Dis 91:771. doi:10.1094/PDIS-91-6-0771B

Schillinger WF, Young DL, Kennedy AC, Paulitz TC (2010) Diverse notill irrigated crop rotations instead of burning and plowing continuous wheat. F Crop Res 115:39-49. doi:10.1016/j.fcr.2009.10.001

Schmidt CS, Agostini F, Leifert C et al (2004) Influence of soil temperature and matric potential on sugar beet seedling colonization and suppression of Pythium damping-off by the antagonistic bacteria Pseudomonas fluorescens and Bacillus subtilis. Phytopathology 94:351-363. doi:10.1094/PHYTO.2004.94.4.351

Schmitthenner AF, Canaday CH (1983) Role of chemical factors in development of Phytophthora diseases. In: Erwin DC, BartnickiGarcia S, Tsao PH (eds) Phytoplithora its Biol. Taxon. Ecol. Pathol. American Phytopathological Society, St. Paul, pp 175-187

Schmitthenner AF, Van Doran DM (1985) Integrated control of root rot of soybean caused by Phytophthora megasperma f. sp. glycinea. In: Parker CA, Rovira AD, Moore KJ et al (eds) Ecol. Manag. Soilborne plant Pathog. American Phytopathological Society, St. Paul, pp 263-266 
Schroeder KL, Martin FN, de Cock AWAM et al (2012b) Molecular detection and quantification of Pythium species: evolving taxonomy, new tools, and challenges. Plant Dis 97:4-20. doi:10.1094/PDIS03-12-0243-FE

Schwanck AA, Meneses PR, Farias CRJ et al (2015) Bipolaris oryzae seed borne inoculum and brown spot epidemics in the subtropical lowland rice-growing region of Brazil. Eur J Plant Pathol 142:875885. doi:10.1007/s10658-015-0659-y

Shang H, Chen J, Goodman J, Handelsman RM (1999) Behavior of Pythium torulosum zoospores during their interaction with tobacco roots and Bacillus cereus. Curr Microbiol 38:199-204

Smiley RW, Uddin W, Ott S, Rhinhart KEL (1990) Influence of flutolonil and tolclofos-methyl on root and culm diseases of winter wheat. Plant Dis 74:788-791

Sneh B, Burpee L, Ogoshi A (1991) Identification of Rhizoctonia species. American Phytopathological Society, St Paul

Starkey T, Enebak SA (2012) Rhizoctonia blight of southern pines. In: Cram MM, Frank MS, Mallams KM (eds) For. Nurs. Pests. USDA Forest Service. Agriculture Handbook, Washington DC, pp 63-65

Stewart-Wade SM (2011) Plant pathogens in recycled irrigation water in commercial plant nurseries and greenhouses: their detection and management. Irrig Sci 29:267-297. doi:10.1007/s00271-0110285-1

Stout M, Davis J (2009) Keys to the increased use of host plant resistance in integrated pest management. In: Peshin R, Dhawan AK (eds) Integr. Pest Manag. Innov. Process, vol 1. Springer Netherlands, Dordrecht, pp 163-181

Summerell BA, Salleh B, Leslie JF (2003) A utilitarian approach to Fusarium identification. Plant Dis 87:117-128. doi:10.1094 /PDIS.2003.87.2.117

Tachibana H (1983) Association of Phytophthora root rot of soybean with conservation tillage. Phytopathology 73:844

Taylor RJ, Salas B, Secor GA et al (2002) Sensitivity of North American isolates of Phytophthora erythroseptica and Pythium ultimum to mefenoxam (metalaxyl). Plant Dis 86:797-802. doi:10.1094 /PDIS.2002.86.7.797

Tillotson CR (1917) Nursery practice on the national forests. USDA Bull 479:86

Tint H (1945) Studies in the Fusarium damping-off of conifers. II. Relation of age of host, $\mathrm{pH}$, and some nutritional factors to the pathogenicity of Fusarium. Phytopathology 35:440-457

Triky-Dotan S, Yermiyahu U, Katan J, Gamliel A (2005) Development of crown and root rot disease of tomato under irrigation with saline water. Phytopathology 95:1438-1444. doi:10.1094/PHYTO-951438

Ünal F, Sara Dolar F (2012) First report of Rhizoctonia solani AG 8 on wheat in Turkey. J Phytopathol 160:52-54. doi:10.1111/j.14390434.2011.01856.x

UNEP (2006) Handbook for the Montreal protocol on substances that deplete the ozone layer (seventh edition)

van der Plank JE (1963) Plant disease: epidemics and control. Academic Press, New-York, London

van Dijk K, Nelson EB (2000) Fatty acid competition as a mechanism by which Enterobacter cloacae suppresses Pythium ultimum sporangium germination and damping-off. Appl Environ Microbiol 66: 5340-5347

Vidya Sagar B, Krishna Rao V, Varaprasad KS (2012) Interaction of Rhizoctonia solani and meloidogyne incognita on tomato. Indian $\mathrm{J}$ Nematol 42:66-70

Vitale A, Castello I, D'Emilio A, Mazzarella R, Perrone G, Epifani F, Polizzi G (2013) Short-term effects of soil solarization in suppressing Calonectria microsclerotia. Plant Soil 368:603-617. doi:10.1007/s11104-012-1544-5

Wang PP, Wu XH (2012) First report of sugar beet seedling damping-off caused by Binucleate Rhizoctonia AG-A in China. Plant Dis 96: 1696. doi:10.1094/PDIS-05-12-0492-PDN
Wang X, Sun C, Gao S et al (2001) Validation of germination rate and root elongation as indicator to assess phytotoxicity with Cucumis sativus. Chemosphere 44:1711-1721. doi:10.1016/S0045-6535(00)00520-8

Weiland JJ, Sundsbak JL (2000) Differentiation and detection of sugar beet fungal pathogens using PCR amplification of actin coding sequences and the ITS region of the rRNA Gene. Plant Dis 84:475482. doi:10.1094/PDIS.2000.84.4.475

Weiland J, Littke W, Haase D (2013) Forest nurseries face critical choices with the loss of methyl bromide fumigation. Calif Agric 67:153-161

Weiland JE, Santamaria L, Grünwald NJ (2014) Sensitivity of Pythium irregulare, $P$. sylvaticum, and P. ultimum from forest nurseries to mefenoxam and fosetyl-Al, and control of Pythium damping-off. Plant Dis 98:937-942. doi:10.1094/PDIS-09-13-0998-RE

Wen B (2015) Effects of high temperature and water stress on seed germination of the invasive species Mexican sunflower. PLoS One 10: 1-13. doi:10.1371/journal.pone.0141567

Whipps JM (2001) Microbial interactions and biocontrol in the rhizosphere. J Exp Bot 52:487-511. doi:10.1093/jexbot/52.suppl_1.487

Wijetunga C, Baker R (1979) Modeling of phenomena associated with soil suppressive to Rhizoctonia solani. Ecol Epidemiol 69:12871293

Wong DH, Barbetti MJ, Sivasithamparam K (1984) Effects of soil temperature and moisture on the pathogenicity of fungi associated with root rot of subterranean clover. Aust J Agric Res 35:675-684

Workneh F, Yang XB, Tylka GL (1998) Effect of tillage practices on vertical distribution of Phytophthora sojae. Plant Dis 82:1258 1263. doi:10.1094/PDIS.1998.82.11.1258

Wright E (1944) Damping-off in broadleaf nurseries of the Great Plains Region. J Agric Res 69:77-94

Wright E (1957) Influence of temperature and moisture on damping-off of American and Siberian elm, black locust, and desertwillow. Phytopathology 47:658-662

Wright SAI, Zumoff CH, Schneider L, Beer SV (2001) Pantoea agglomerans strain EH318 produces two antibiotics that inhibit Erwinia amylovora in vitro. Appl Environ Microbiol 67:282-292. doi:10.1128/AEM.67.1.284-292.2001

Yang GH, Conner RL, Chen YY (2007) First report of damping-off of Swiss chard caused by Rhizoctonia solani AG-4 HG I and Binucleate Rhizoctonia AG-A in China. Plant Dis 91:1516. doi:10.1094/PDIS-91-11-1516A

Yangui T, Rhouma A, Triki MA et al (2008) Control of damping-off caused by Rhizoctonia solani and Fusarium solani using olive mill waste water and some of its indigenous bacterial strains. Crop Prot 27:189-197. doi:10.1016/j.cropro.2007.05.005

Yitbarek SM, Verma PR, Gugel RK, Morrall RAA (1988) Effect of soil temperature and inoculum density on pre-emergence damping-off of canola caused by Rhizoctonia solani. Can J Plant Pathol 10:93-98. doi:10.1080/07060668809501739

You MP, Sivasithamparam K, Riley IT, Barbetti MJ (2000) The occurrence of root-infecting fungi and parasitic nematodes in annual Medicago species in Western Australian pastures. Aust J Agric Res 51:435-444

Zappia RE, Huberli D, Hardy GESJ, Bayliss KL (2014) Fungi and oomycetes in open irrigation systems: knowledge gaps and biosecurity implications. Plant Pathol 63:961-972. doi:10.1111 /ppa.12223

Zhang XY, Huo HL, Wang W et al (2015) First report of damping-off and seedling blight on oat caused by Rhizoctonia solani AG 2-1 in China. Plant Dis 100:653. doi:10.1094/PDIS-09-15-0968-PDN

Zinger L, Gobet A, Pommier T (2012) Two decades of describing the unseen majority of aquatic microbial diversity. Mol Ecol 21:18781896. doi:10.1111/j.1365-294X.2011.05362.x

Zitnick-Anderson KK, Nelson BD (2014) Identification and pathogenicity of Pythium on soybean in North Dakota. Plant Dis 99:31-38. doi:10.1094/PDIS-02-14-0161-RE 